\title{
Is there a role for mast cells in psoriasis?
}

\author{
Ilkka T. Harvima · Gunnar Nilsson • \\ Mireille-Maria Suttle $\cdot$ Anita Naukkarinen
}

Received: 27 April 2008 / Revised: 17 June 2008 / Accepted: 20 June 2008 / Published online: 22 August 2008

(C) Springer-Verlag 2008

\begin{abstract}
Mast cells have traditionally been considered as effector cells in allergy but during the last decade it has been realized that mast cells are essentially involved in the mechanisms of innate and acquired immunity. Upon activation by anaphylactic, piecemeal degranulation or degranulation-independent mechanisms mast cells can secrete rapidly or slowly a number of soluble mediators, such as serine proteinases, histamine, lipid-derived mediators, cytokines, chemokines and growth factors. Mast cells can express cell surface co-stimulatory receptors and ligands, and they can express MHC class II molecules and thereby present antigens. These soluble factors and cell surface molecules can interact with other cells, such as endothelial cells, keratinocytes, sensory nerves, neutrophils, T cell subsets and antigen presenting cells which are essential effectors in the development of skin inflammation. Besides promoting inflammation, mast cells may attempt in some circumstances to suppress the inflammation and epidermal growth but the regulation between suppressive and proinflammatory mechanisms is unclear. Psoriasis is characterized by epidermal hyperplasia and chronic inflammation
\end{abstract}

I. T. Harvima $(\bowtie) \cdot$ M.-M. Suttle

Department of Dermatology,

Kuopio University Hospital and University of Kuopio,

P O. Box 1777, 70211 Kuopio, Finland

e-mail: ilkka.harvima@kuh.fi

G. Nilsson

Department of Medicine,

Karolinska Institutet, Stockholm, Sweden

A. Naukkarinen

Department of Pathology,

Kuopio University Hospital, Kuopio, Finland where tryptase- and chymase-positive $\mathrm{MC}_{\mathrm{TC}}$ mast cells are activated early in the developing lesion and later the cells increase in number in the upper dermis with concomitant expression of cytokines and TNF superfamily ligands as well as increased contacts with neuropeptide-containing sensory nerves. Due to the intimate involvement of mast cells in immunity and chronic inflammation the role of mast cells in psoriasis is discussed in this review.

Keywords Mast cell $\cdot$ Mediator · Psoriasis $\cdot$ Proteinase · Cytokine $\cdot$ Nerve $\cdot$ Pathogenesis

\section{Introduction}

Mast cells are long-lived cells that are strategically located at sites, such as the upper dermal skin, respiratory tract and bowel mucosa, where the host tissue is exposed to external antigens and microbes. Human mast cells can be divided into $\mathrm{MC}_{\mathrm{TC}}$ and $\mathrm{MC}_{\mathrm{T}}$ subtypes based on their proteinase composition: $\mathrm{MC}_{\mathrm{TC}}$ cells contain tryptase, chymase, carboxypeptidase and a cathepsin G-like proteinase whereas $\mathrm{MC}_{\mathrm{T}}$ cells contain only tryptase $[78,162,202] . \mathrm{MC}_{\mathrm{C}}$ mast cell type with only chymase and carboxypeptidase has also been identified in human tissues [202] though there are results from skin organ cultures suggesting that it may represent an apoptotic mast cell from which tryptase has dissolved away [96]. $\mathrm{MC}_{\mathrm{TC}}$ mast cell is the predominant cell type in the skin and bowel submucosa, whereas $\mathrm{MC}_{\mathrm{T}}$ cells predominate in the lung and bowel mucosa [78, 202].

Traditionally, mast cells are known to be activated to release mediators by allergen cross-linking IgE molecules and their high affinity Fc\&RI receptors on the cell membrane. However, the activation mechanisms are far more complex and versatile. In addition to IgE-dependent mechanism, 
human skin mast cells can be activated by an IgG-dependent mechanism since they constitutively express the FC $\gamma$ RIIa receptor [217]. Furthermore, the high-affinity IgG receptor, Fc $\gamma \mathrm{RI} / \mathrm{CD} 64$, can be induced in in vitro cultured mast cells by interferon- $\gamma$ [137]. Interestingly, mast cells in the psoriatic lesion, where also interferon- $\gamma$ is expressed, show expression of CD64 [187]. Recently, mast cells have been reported to express a range of toll-like receptors which can be activated by microbial products [29]. Mast cells can also be activated for mediator release by numerous endogenous peptides and proteins, including complement products C3a and C5a [38], neuropeptides, such as substance P (SP) and vasoactive intestinal peptide (VIP) [23], stem cell factor (SCF) [35], tumor necrosis factor (TNF) [192], tryptase [122], and $\alpha$-melanocyte-stimulating hormone [56]. Corticotropin-releasing hormone has been found to induce selective release of vascular endothelial growth factor (VEGF) from human mast cells [17], a factor which is essentially involved in angiogenesis and capillary growth. Human mast cell activation by means of reverse signalling through CD30 ligand is a novel pathway for mast cell activation and chemokine secretion [42]. It should be realized that the activation of mast cells for mediator release is not simply an on-off mechanism, i.e., no activation or rapid and extensive anaphylactic degranulation. Mast cells can undergo also slow peacemeal degranulation [34], exosome secretion [172], and selective degranulation-independent mediator secretion $[17,42]$.

The physiological role of mast cells in the skin is not well known. It appears that mast cells are essential effector cells in protecting the skin from, e.g., severe bacterial and parasite infections $[113,171]$ and from severe venom reactions after snake bites and insect stings [117]. However, there is growing evidence suggesting that mast cells are also essentially involved in inflammatory pathomechanisms of chronic diseases. This is understandable since mast cells can produce, store and release upon activation numerous mediators that can potentially affect the immune system and promote inflammation. These can be categorised into preformed mediators and newly-synthesized mediators. Preformed mediators stored in the secretory granules include, e.g., tryptase, chymase, carboxypeptidase, a cathepsin Glike proteinase, histamine, heparin proteoglycan, chondroitin sulphate $\mathrm{E}$, acidic hydrolases, and various cytokines and growth factors. Newly synthesized mediators include prostaglandin $\mathrm{D}_{2}$, leukotriene $\mathrm{C}_{4}$ and varying amounts of other lipid-derived mediators. In addition, mast cells can be induced to de novo synthesis of a range of cytokines, chemokines, growth factors, and cell membrane molecules, such as chemokine receptors, receptor ligands, toll-like receptors, MHC class II molecules and co-stimulatory molecules, all of which are crucial in inducing an immune and inflammatory reaction $[29,46,83,160]$.
Psoriasis is characterized by chronic inflammation and epidermal hyperplasia where numerous inflammatory and immune cells function simultaneously, and the involvement of mast cells in this complex cellular and molecular network has become obvious. During the last decade many reports have shown that mast cells are not just bystander cells in inflammatory diseases but rather crucial for immunity as reported in a news article entitled "Mast cells show their might" (Science 2007; 317:614-616). Therefore, in this review the role of mast cells in the development of psoriatic lesion is discussed.

\section{Mast cells in the psoriatic lesion}

The presence of numerous mast cells in the psoriatic lesion, especially in the subepidermal connective tissue, was recognized many decades ago as reviewed by Cox [27]. After these observations, several other investigators confirmed that the number of mast cells is increased in the upper dermis of the psoriatic lesion [59, 60, 80, 189], and it is the $\mathrm{MC}_{\mathrm{TC}}$ type of mast cells that are increased in number in the uppermost dermis of the psoriatic lesion [61]. However, this change is not specific to psoriasis since $\mathrm{MC}_{\mathrm{TC}}$ mast cells are similarly increased in number in superficial spreading basal cell carcinoma [31], and mast cells in chronic leg ulcers are predominantly of this $\mathrm{MC}_{\mathrm{TC}}$ type [74]. Even though mast cells can only rarely be seen in the epidermis of the healthy-looking skin, the presence of mast cells in close association with the epidermis of the psoriatic lesion is a typical feature and sometimes mast cells are present even inside the lesional epidermis [59]. Intraepidermal mast cells, however, have also been associated with other chronic inflammatory skin diseases with epidermal proliferation, such as pemphigus vegetans, dermatitis vegetans and pseudoepitheliomatous diseases [53] as well as chronic leg ulcers [11].

The appearance of degranulated mast cells is a typical feature in the early developing psoriatic lesion as reported by several investigators $[13,27,168]$. Schubert and Christophers [168] treated psoriatic plaques with a potent steroid under occlusion for 6-10 days and then allowed a relapse to occur. During the developing relapse, the earliest changes were found to be endothelial swelling followed by the appearance of degranulated mast cells around the postcapillary venules, and hours later activated macrophages were present. Brody [13] examined a series of biopsies taken from the early phases of acute eruptive guttate psoriasis and demonstrated different types of mast cell degranulation in the psoriatic lesion. He reported that degranulated mast cells are an early and constant feature in the evolution of acute guttate psoriasis. Toruniowa and Jablonska [188] induced a Köbner reaction in the healthy-looking psoriatic 
skin and analyzed biopsies taken from the developing lesion. A significant increase in mast cell numbers took place on day 4 , when compared to mast cell numbers in control skin, and this increase peaked on day 14 simultaneously with the appearance of the Köbner's phenomenon. These findings suggest that mast cells residing in the dermis are among the earliest cells which show activation in the initial phases leading to mast cell degranulation and increase in cell number. The increased interstitial histamine concentration in the psoriatic plaque, as measured with the microdialysis technique, also suggests elevated mast cell activity and degranulation [97, 147].

\section{Regulation of mast cell number and activity in the psoriatic skin}

The mechanisms for the increase in mast cell numbers in chronic inflammation, such as in psoriasis, is not clear. The stem cell factor (SCF) (Kit ligand) is a well-known and essential factor for the growth, migration, activation and survival of human mast cells developed and cultured in vitro $[93,123,133,134]$ or isolated from skin specimens $[45,85]$. SCF injected subcutaneously induces anaphylactic-like activation and degranulation of dermal mast cells in situ followed by inflammatory cell recruitment such as neutrophils, eosinophils and basophils [35]. Prolonged subcutaneous injection of SCF for up to 14 days results in mast cell and melanocyte hyperplasia in the skin [26]. Mature mast cells isolated from human skin specimens can be cultured in serum-free medium in the presence of SCF, and these cells even proliferate and maintain their proteinase phenotype in such conditions [85] suggesting that a mature $\mathrm{MC}_{\mathrm{TC}}$ mast cell is capable of proliferation in response to SCF during a disease process. In a mouse model of skin inflammation, Kit expression is essential for mast cell accumulation which further supports the importance of SCF-Kit interaction [201]. Another explanation for the increased mast cell numbers may be that the survival of resting and activated mast cells is enhanced due to survival gene expression or other mechanisms $[148,210]$ and/or mast cells and their hematopoietic progenitors are recruited from the circulation. For example, mast cells express at least nine chemokine receptors [83] and SCF, TGF- $\beta$, RANTES and stromal cellderived factor- $1 \alpha$ have efficiently induced migration of human mast cells in vitro and therefore they are potent candidates for chemoattraction of mast cells to the tissue site $[82,132,139]$. In addition to SCF, several other factors have been reported to modulate human mast cell development or survival in vitro, such as IL-3 to IL-6 [213], IL-9 [112], thrombopoietin [158], nerve growth factor [89], and endothelial cells [118].
Since SCF is the crucial factor for mast cell growth, migration and survival, the expression of SCF in inflamed skin has previously been studied. Yamamoto et al. [212] demonstrated that SCF immunoreactivity is localized to keratinocytes in the acanthotic psoriatic epidermis and also to endothelial cells and fibroblasts. In addition, serum levels of SCF were increased in psoriatic patients compared with those in normal subjects [212]. Furthermore, the number of SCF-positive cells is markedly higher in the dermis and epidermis of the psoriatic lesion than in those of corresponding non-lesional skin [73]. The increase of SCF in inflamed psoriatic skin is, however, not a specific feature of psoriasis since SCF-positive cells are numerous also in chronic leg ulcers and transiently increased in number in the initial phases of normal wound healing [73]. Furthermore, SCF is increasingly upregulated in basal cell carcinoma and also in tumor cells [211]. Interestingly, even mast cells themselves can produce SCF [203, 215]. The receptor for SCF, Kit, is a transmembrane tyrosine kinase receptor that is practically exclusively expressed by mast cells in the dermis and by melanocytes in the epidermis $[67,73]$. In the psoriatic lesion, mast cells are strongly immunopositive for Kit when compared to mast cells in the non-lesional skin (Table 1) [73]. However, Kit is strongly expressed in mast cells in chronic leg ulcers and in the late phases of normal wound healing as well [73]. Therefore, the SCF-Kit interaction provides one plausible explanation for the increase in mast cell numbers and enhanced mast cell activity in chronic skin inflammation, including psoriasis.

Several effective drugs used in the treatment of psoriasis can affect the activity and/or number of mast cells. Lowstrength anthralin therapy has been found to reduce the number of mast cells in the psoriatic plaque [188]. The treatment with $0.05 \%$ clobetasol-17-propionate cream for up to 4 weeks inhibits allergen-induced wheal reaction and reduces markedly the number of mast cells in the skin [151]. Corticosteroids may possibly inhibit the production of SCF in dermal cells leading to reduced survival of mast cells [41]. However, a topical clobetasol-17-propionate treatment of psoriatic plaques for up to 3-4 weeks did not result in a decrease in mast cell number, nor did the 3- to 4week treatment with bath-PUVA, and a longer treatment period appears to be required in order to deplete mast cell hyperplasia in the chronic psoriatic plaque [189]. This resistance of mast cells to topical corticosteroid may be explained by highly increased SCF production in psoriasis $[73,212]$. Retinoids, which are widely used in the treatment of psoriasis, have been reported to inhibit the development of human mast cells from progenitors in vitro [67, 92] but without reducing the number of mature mast cells in the normal human skin [67]. Also, retinoids have been found to inhibit histamine release from concanavalin-A stimulated human mast cells isolated from the adenoid tissue [37]. 
Table 1 The percentage of tryptase-positive mast cells immunopositive for different proteins in the upper dermis of the psoriatic skin based on the sequential double-staining technique

\begin{tabular}{|c|c|c|c|c|}
\hline & Nonlesional skin & Lesional skin & $\begin{array}{l}\text { Number } \\
\text { of subjects }\end{array}$ & References \\
\hline Kit & $46 \pm 26 \%$ & $88 \pm 12 \%$ & 10 & {$[73]$} \\
\hline$\alpha_{1}$-Proteinase inhibitor & $33 \pm 19 \%$ & $72 \pm 15 \%$ & 20 & {$[62]$} \\
\hline$\alpha_{1}$-Antichymotrypsin & $60 \pm 13 \%$ & $87 \pm 7 \%$ & 20 & {$[62]$} \\
\hline$\alpha_{2}$-Macroglobulin & $6 \pm 4 \%$ & $17 \pm 7 \%$ & 10 & {$[62]$} \\
\hline C1-esterase inhibitor & $11 \pm 6 \%$ & $14 \pm 10 \%$ & 5 & {$[62]$} \\
\hline Interferon- $\gamma$ & $44 \pm 17 \%$ & $67 \pm 18 \%$ & 21 & {$[2]$} \\
\hline TNF- $\alpha$ & $15 \pm 15 \%$ & $16 \pm 25 \%$ & 12 & {$[1]$} \\
\hline CD30 ligand & $8 \pm 11 \%$ & $33 \pm 21 \%$ & 10 & [42] \\
\hline Tryptase-positive cells & $96-130$ cells $/ \mathrm{mm}^{2}$ & $257-308$ cells $/ \mathrm{mm}^{2}$ & & $\begin{array}{l}\text { (data compiled from } \\
\text { references listed above) }\end{array}$ \\
\hline
\end{tabular}

The sequential double-staining technique used to generate these results is illustrated in Fig. 2

Thus, one therapeutic action of retinoids may be targeted to inhibition of mast cell activity as well as maturation of recruited progenitor mast cells entered to the tissue site. Cyclosporin A is also a potent immunomodulatory drug used in the treatment of psoriasis. However, besides its well-known inhibitory action on $\mathrm{T}$ cells cyclosporin $\mathrm{A}$ has long been known to inhibit histamine and $\mathrm{LTC}_{4}$ or $\mathrm{PGD}_{2}$ release from isolated human lung or skin mast cells [110, 177]. Cyclosporin A can also inhibit SCF-induced histamine release [173] as well as chemokine gene induction in human mast cells [68]. Moreover, subcutaneous injections of cyclosporin A into asebia mice, which show epidermis hyperplasia and dermal inflammatory changes with elevated mast cell numbers, have been found to decrease mast cell numbers in the dermis [141]. Thus, a part of the therapeutic effect of cyclosporin A in psoriasis may be attributed to the inhibition of mast cell activity and the decrease in mast cell numbers. In addition to potent immunomodulators, also H1- and $\mathrm{H} 2$-antihistamines have been tested in psoriatic patients [145, 147, 219]. Based on the skin microdialysis technique and histamine assays mast cells in the psoriatic lesion are hyperreactive. A prolonged high-dose ranitidine administration for up to 6 months to psoriatic patients appears to improve psoriatic skin disease and normalize mast cell hyperreactivity towards substance $\mathrm{P}$ and codeine injections, but without affecting mast cell numbers [147]. However, a double-blind and placebo-controlled multicenter study could not reveal any significant therapeutic effect of ranitidine on psoriasis [219]. In a double-blind controlled study, $10 \mathrm{mg}$ cetirizine administered three times a day for 15 days significantly reduced the number of tryptase-positive mast cells in the lesional skin, resulted in some improvement in the psoriatic area and severity index (PASI) score and erythema [145], and reduced the expression of adhesion molecules ICAM-1, ICAM-3 and LFA-1
[146]. Nevertheless, an inhibitor of mast cell degranulation, Tiacrilast, administered topically as a $3 \%$ hydrogel for 4 weeks did not produce any significant improvement in the psoriatic plaques [191].

\section{Mast cell serine proteinases in psoriasis}

The major protein in mast cell granules, tryptase, is a trypsin-like serine proteinase with 4 subunits and catalytic sites and it shows heterogeneity in respect to glycosylated side chains and can follow sigmoidal reaction kinetics typical for allosteric enzymes [58, 64, 144]. The gene locus of human tryptase in the chromosome $16 \mathrm{p} 13.3$ is far more complex than originally thought: there are two major forms, $\alpha$ - and $\beta$-tryptases, which can be divided further into $\alpha 1$ - and $\alpha 2$-forms and $\beta 1$-, $\beta 2$ - and $\beta 3$-forms. Furthermore, additional forms include $\gamma$-, $\varepsilon$ - and $\delta$-tryptases $[19,20,199$, $207,214]$ of which $\gamma$-tryptase is a functionally and structurally distinct membrane-bound enzyme in mast cells that can efficiently be inactivated by $\alpha_{1}$-proteinase inhibitor [208, 214], $\varepsilon$-tryptase is expressed in airway epithelial cells but apparently not markedly in mast cells [207], and $\delta$-tryptase has marked amino acid similarity with $\alpha$ - and $\beta$-tryptases but is truncated by 40 amino acids in the carboxyterminal end and cannot hydrolyze the canonical tryptase substrate $N$-p-tosyl-Gly-Pro-Lys- $p$-nitronilide [199]. There is, however, a report showing that $\delta$-tryptase gene is a pseudogene without transcription in human mast cells in vitro [119]. Nevertheless, inactive $\alpha$ - and $\beta$-protryptases are constitutively secreted and active $\beta$-tryptase is the principal enzyme that is packed and stored in large quantities in the secretory granules of mast cells [64, 169]. Human $\beta$-tryptase is a ring-like tetramer with four active centers facing towards the central oval pore [144]. This feature explains the high 
selectivity of the catalytic action of $\beta$-tryptase on different proteins and peptides since a protein has to be in a proper orientation and has to possess a suitable conformation to reach the buried active centers. Indeed, $\beta$-tryptase is resistant to common endogenous protease inhibitors and, in fact, there are no known physiologic inhibitors for tetrameric $\beta$-tryptase. Furthermore, heparin glycosaminoglycan is needed to stabilize $\beta$-tryptase as an active tetramer and degradation of heparin or replacement of $\beta$-tryptase from heparin by another protein or molecule can be physiological control mechanisms - in the absence of heparin tetrameric $\beta$-tryptase dissociates reversibly into inactive-destabilized tetramer and further to inactive monomers and monomers with limited activity [57, 64, 164]. In accordance with this resistance to protease inhibitors, tryptase has been found to be catalytically active detected on skin sections from inflamed skin and only occasional tryptase immunoreactive cells without enzyme activity have been detected [31, 61, 86].

In contrast to tryptase, only a single $\alpha$-form of human chymase gene has been found in the protease gene locus in chromosome 14q11.1-11.2 next to cathepsin G gene. Mature chymase is a $30-\mathrm{kDa}$ monomeric and chymotryptic serine proteinase that is processed from prochymase by dipeptidyl peptidase I and is stored in high quantities in mast cell secretory granules [19, 20]. Even though both tryptase and chymase bind efficiently to heparin, chymaseheparin proteoglycan complexes $\left(M_{\mathrm{r}} 400-560 \mathrm{kDa}\right)$ are larger in size than tryptase-heparin proteoglycan complexes $\left(M_{\mathrm{r}} 200-250 \mathrm{kDa}\right)$ [52]. Furthermore, the subcellular localization of chymase differs from that of tryptase within the secretory granules - chymase and cathepsin G are preferentially localized in more electron-dense amorphous granule subregions whereas tryptase resides in less electron-dense crystalline subregions [205]. These differences may explain the findings that tryptase protein diffuses away together with histamine whereas chymase protein tends to remain at the site of mast cells in human skin biopsies cultured and activated ex vivo $[95,96]$. Thus, tryptase can diffuse through the extracellular matrix and reach more distant target sites in the skin whereas chymase functions rather locally. However, different forms of chymase have been described in respect to the binding affinity to heparinagarose column, possibly owing to differences in glycosylation, and therefore chymase form with low binding affinity may diffuse more easily after release than the high-affinity form [114]. Although chymase binds efficiently to heparin, the enzyme remains active also in the absence of heparin, a feature which differs from that of tryptase. However, heparin can modulate the interaction of chymase with cells, protein substrates and inhibitors [74, 159, 195]. A clearly distinct feature of chymase is that it can be inactivated by a range of endogenous protease inhibitors, including $\alpha_{1}$-pro- teinase inhibitor $\left(\alpha_{1}\right.$-PI), $\alpha_{1}$-antichymotrypsin $\left(\alpha_{1}\right.$-AC) [114, 161] $\alpha_{2}$-macroglobulin [196], secretory leukocyte proteinase inhibitor [195] and squamous cell carcinoma antigen-2 [165]. However, chymase can also effectively degrade $\alpha_{1}$-PI and $\alpha_{1}$-AC and, in fact, this reaction proceeds faster than the inhibition of chymase by these inhibitors [161] suggesting a complex regulation between the proteinase and its inhibitors. Thus, the activity of chymase is controlled by protease inhibitors normally present in inflamed tissue whereas tryptase may have a prolonged action time after being released from mast cells. In support for this, inactivation of chymase has been shown to take place rapidly in the skin, e.g., in the allergic skin wheal reaction [155], cutaneous herpes zoster lesions [86] and skin organ cultures $[95,96]$, as detected enzyme- and immunohistochemically.

The $\mathrm{MC}_{\mathrm{TC}}$ type of mast cell with tryptase and chymase is the predominant mast cell type in normal skin and these mast cells are increased in number in the upper dermis of the psoriatic lesion. However, meanwhile tryptase retains its activity chymase is apparently inactivated in the upper dermis during the development of the psoriatic lesion [5961]. Using the sequential double-staining technique, mast cells in the psoriatic lesion have been shown to display increased levels of immunoreactivity towards $\alpha_{1}$-PI, $\alpha_{1}$-AC, $\alpha_{2}$-macroglobulin and even C1-esterase inhibitor (Table 1). Further, $\alpha_{1}$-AC-positive mast cells appeared to correlate with reduced chymase activity in the lesion [62]. It is possible that these inhibitors are derived from the extravasated serum and taken up by mast cells as is suggested in the case of inter- $\alpha$-trypsin inhibitor light chain [76], or produced in mast cells as in the case of secretory leukocyte proteinase inhibitor [204]. Nevertheless, the increased levels of $\alpha_{1}$-AC and $\alpha_{1}$-PI within mast cells could well explain the reduced chymase activity. This feature, however, is not specific to psoriasis, since it has been detected, for example in basal cell carcinoma [31] as well as chronic leg ulcers [74]. The activation of mast cells in the inflamed skin may lead to granule extrusion and hence loosening of tightly packed acidic granule structure. Inhibitors presumably can then inactivate chymase exposed to physiological $\mathrm{pH}$ and high inhibitor concentration (Fig. 1). It is noteworthy, however, that the apparent inactivation of chymase is only partial and there is residual chymase activity which may affect the surrounding microenvironment [61, 62].

Mast cells contain large amounts of preformed $\beta$-tryptase and $\alpha$-chymase and their possible function in the inflammatory process cannot be ignored [20]. Even though the pathophysiological significance of $\beta$-tryptase in vivo is not clear, there are several experimental findings which suggest an implication for the development of psoriatic inflammation. Tryptase has been reported to induce vascular tube formation of endothelial cells in vitro suggesting a 

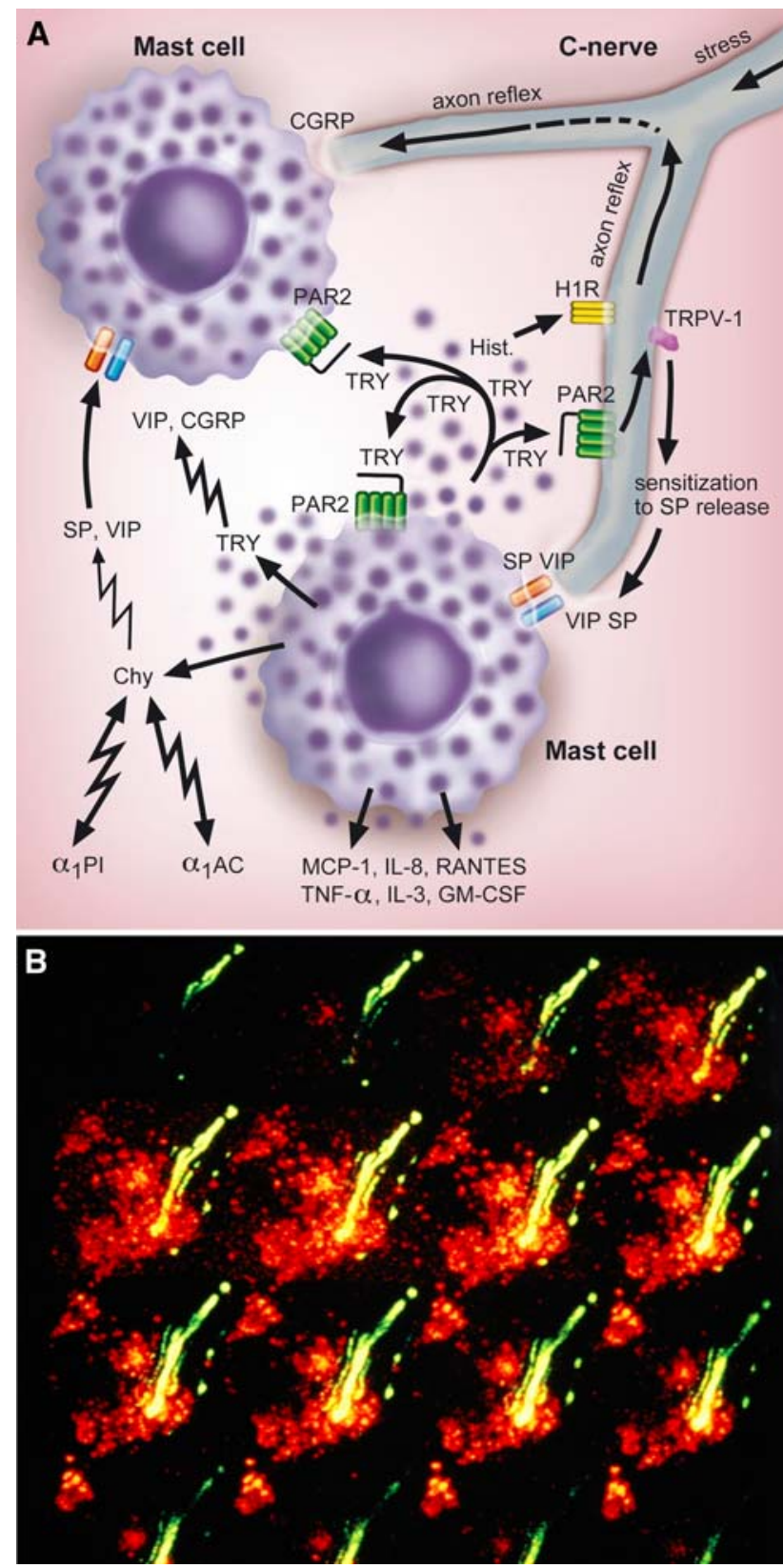

role in angiogenesis [10]. In addition, tryptase can stimulate human endothelial cells for increased production of MCP-1 and IL-8 [24, 25, 91], chemokines which can attract neutrophils and many other cells of the immune system. Furthermore, tryptase activates peripheral blood mononuclear cells for TNF- $\alpha$, IL-6 and IL-1 $\beta$ production [109], human neutrophils for IL-8 secretion [197], and human T cells for IL6 release [101]. Activation of these cells is very likely mediated via activation of the proteinase-activated receptor-2 (PAR-2) by tryptase. In experimental animals, tryptase injected into the skin of guinea pigs induced accumulation of neutrophils and eosinophils within $6 \mathrm{~h}$ and later also other cells of the immune system [65]. In addition, also human skin mast cells express the PAR-2 receptor and can
4 Fig. 1 Hypothetical model for the interaction between mast cells and sensory nerves in psoriasis. a Neuropeptides substance P (SP) and vasoactive intestinal peptide (VIP) released from sensory nerves can activate mast cells for mediator synthesis and release by a receptordependent or -independent mechanism. Tryptase (Try) released can diffuse through the matrix, reach more distant sites, and can degrade and inactivate VIP and calcitonin gene-related peptide (CGRP), but not SP. Released chymase (Chy) tends to remain at the site of activated mast cell, it can degrade both SP and VIP, but is partially inactivated by $\alpha_{1}$ proteinase inhibitor $\left(\alpha_{1}\right.$-PI) and $\alpha_{1}$-antichymotrypsin $\left(\alpha_{1}\right.$-AC). On the other hand, chymase can degrade these inhibitors efficiently. Histamine and tryptase can activate the sensory nerve resulting in the spread of the signal in an axon reflex-dependent mechanism. The tryptase receptor on nerves, proteinase-activated receptor-2 (PAR-2), is in relation to the capsaicin receptor (TRPV-1) and PAR-2 activation sensitizes TRPV-1 leading to enhancement in capsaicin-induced SP and CGRP release. Tryptase can also activate PAR-2 on mast cells potentiating the reaction in an autocrine or paracrine fashion. $\mathbf{b}$ A confocal laser scanning image of a neurofilament-positive sensory nerve and a tryptase-immunopositive mast cell (see [131]). In the dermis of a mature psoriatic lesion, a bundle of nerves (green) appears in the first image up left. Step by step mast cell tryptase (red) becomes visible, and the nerves are observed in close contact with the mast cell in most images where the nerves appear yellow. At those sites, the red of mast cell tryptase coincides with the green colour of neurofilaments. Sixteen consecutive laser scanning images, step size $0.2 \mu \mathrm{m}$

thus be activated by tryptase and receptor agonists [122]. Furthermore, the percentage of mast cells showing PAR-2 immunoreactivity is increased in the psoriatic lesion (Carvalho et al., unpublished results). This suggests that tryptase released from mast cells can induce mast cell activation in an autocrine or paracrine fashion leading to potentiation of mast cell-mediated inflammation in psoriasis (Fig. 1). Besides its proinflammatory function tryptase may also control cell recruitment to some extent since it is capable of cleaving eotaxin and RANTES, but not GM-CSF, MCP-1, IL-8, TGF- $\beta 1$ and VEGF [142]. Tryptase-positive mast cells are increased in number close to the psoriatic epidermis and, therefore, the enzyme may well affect the basement membrane and basal keratinocytes. Indeed, tryptase has been found to degrade fibronectin in the basement membrane zone [87]. In addition, tryptase can activate metalloproteinases, such as MMP-3 and MMP-9 [55, 75, 102], and pro-urokinase [174], or it can act as a gelatinase [39]. Thus, tryptase can modify the extracellular matrix and basement membrane directly or indirectly in order to make space for $\mathrm{T}$ cells and neutrophils for migrating into the epidermis. Tryptase may also affect keratinocytes directly via activation of PAR-2 on their surface [163]. Interestingly, in vitro activation of keratinocytes by PAR-2 agonists results in increased keratinocyte phagocytosis [170], ICAM-1 expression [14] and IL-8 release [70]. Furthermore, tryptase has been reported to stimulate bronchial epithelial cells to release IL-8 and express ICAM-1 [16].

Like tryptase, chymase also can have immunoregulatory activity which may be related to the psoriatic immunopathogenesis, though the effect is dependent on the availability of 
enzymatically active chymase in an environment rich in protease inhibitors. Human chymase injected into the skin of guinea pigs stimulates the accumulation of neutrophils and eosinophils at the injection sites [66]. In support for this, chymase also stimulates chemotaxis of monocytes, and neutrophils and chemokinesis of lymphocytes in vitro [183]. Interestingly, chymase has been reported to stimulate an eosinophilic cell line EoL-1 for IL-8 synthesis and secretion in vitro [186]. Chymase can also activate the precursors of IL-1 family, pro-IL- $1 \beta$ and pro-IL-18, to their corresponding active forms IL-1 $\beta$ and IL-18 [120, $140]$. In addition, it can generate 31 -amino acid endothelin-1 that acts as a potent chemoattractant for neutrophils and monocytes [28], and therefore chymase may promote inflammation indirectly. Another indirect mechanism could be the cleavage of membrane-bound SCF on stromal cells by chymase, which results in the release of soluble and bioactive SCF. Thus, the released SCF may have an effect on mast cell activity and growth during inflammation [103]. Furthermore, chymase has been shown to release matrix-bound latent TGF- $\beta 1$ complexes in vitro and therefore it may participate in the regulation of the immune system and matrix accumulation [181]. Like tryptase, also chymase may have controlling effects on inflammation since chymase, as well as cathepsin G, can efficiently degrade IL-6 and IL-13, and also IL-5 and TNF- $\alpha$ to some extent, but not GM-CSF [216]. In addition, chymase can degrade eotaxin, but not RANTES, MCP-1 or IL-8 [142]. Chymase is a potent enzyme and has to be controlled by proteinase inhibitors since it can affect the epidermis and cleave epidermal keratinocytes from the substratum leading to keratinocyte apoptosis [74] (Diaconu et al., unpublished results). It can also degrade fibronectin [138] and activate procollagenase [154].

\section{Interactions between mast cells and sensory nerves in psoriasis}

The involvement of stress in cutaneous neurogenic inflammation and sensory nerve-mast cell interaction has been suggested in several studies [6, 143]. Neuropeptides SP and VIP can efficiently activate human skin mast cells for rapid histamine release in situ [71] and in vitro [23]. Furthermore, in vitro stimulation of human mast cells with SP and VIP results in the production of proinflammatory mediators, such as MCP-1, IL-8, RANTES, TNF- $\alpha$, IL-3 and GM-CSF $[48,100]$. However, it appears that the amount of neuropeptides in normal skin is not sufficient for inducing marked mast cell activation, a conclusion based on the findings that capsaicin can induce only weak, if any, histamine release in skin ex vivo and in situ [71, 184]. Nevertheless, the case is different in chronic skin inflammation, since increased SP-positive nerve fibers [128] and increased tissue levels of SP and VIP [36] have been measured in the psoriatic lesion, though there are reports showing only increased VIP levels in the lesional skin [5, 149]. Accordingly, topical capsaicin cream has been reported to be effective in the treatment of psoriatic plaques [9] and the mechanism for this beneficial effect may be that prolonged capsaicin treatment depletes neuropeptides from nerves [178]. Further support for the role of nerves is provided by clinical cases where nerve damage has been reported to clear chronic psoriasis and the lesions reappeared with recovery of cutaneous sensation [40].

In histochemical studies, morphological contacts between neurofilament-positive sensory nerves and tryptase-positive mast cells are more frequent in the developing and mature psoriatic lesions than in lesion-free skin, normal skin and lichen planus skin $[129,130]$. This indicates that the morphological basis exists for nerve-mast cell interaction in psoriasis as illustrated in Fig 1. Furthermore, the contacts between SP- and CGRP-positive fibers and tryptase-positive mast cells are increased in the uppermost dermis of the psoriatic lesion as well, whereas the contacts between VIP-positive fibers and tryptase-positive mast cells were less frequent [131]. This suggests that especially SP- and CGRP-positive nerves interact with mast cells in psoriasis. However, nerve-mast cell interaction and neuropeptides SP and CGRP have also been linked to atopic and nummular eczema lesions [84].

The regulatory system between nerves and mast cells in psoriasis is evidently more complex than thought. For example, higher doses of topical capsaicin are needed to induce inflammation on the forearm skin of psoriatic patients than on that of healthy controls or patients with systemic scleroderma [50]. Even though the basal histamine concentration in the psoriatic lesion is elevated, as measured with the microdialysis technique, the topical anaesthesia with lignocaine-prilocaine cream could not reduce histamine level but rather increased it together with a decrease in blood flow [98]. One possible explanation for this may be given by the state of exhaustion in the neurogenic system in chronic psoriasis. In addition, several proteases can degrade neuropeptides and control their effects. Dipeptidyl peptidase IV (CD26) is present in the psoriatic lesion and can cleave dipeptides from the aminoterminal end of SP [136, 200]. Neutral endopeptidase can terminate SP-induced skin inflammation [167], and stromelysin can cleave SP [185]. The precursor for stromelysin, prostromelysin, can be activated by mast cell tryptase [55]. Furthermore, tryptase can cleave and inactivate VIP and CGRP, but not SP and neurokinins [43, 182, 193]. Chymase is able to degrade both SP and VIP [18, 43] (Fig. 1), and mast cell carboxypeptidase releases carboxyterminal leucine from 
Leu ${ }^{5}$-enkephalin, kinetensin and neurotensin [51]. Besides controlling the neuropeptide-mediated inflammation, tryptase may also promote neurogenic inflammation by activating the PAR-2 receptor on nerves resulting in SP and CGRP release [175]. However, it is not known whether the PAR-2 receptor is upregulated in nerves in psoriasis like it is in atopic dermatitis lesions [176]. Interestingly, PAR-2 appears to be closely related to the capsaicin receptor, transient receptor potential vanilloid receptor-1 (TRPV-1). PAR-2 activation sensitizes TRPV-1 leading to enhancement in capsaicin-induced SP and CGRP release [4]. Furthermore, TRPV-1 has been localized to cutaneous SPpositive nerve fibers and mast cells [178]. Histamine is also a mediator that has traditionally been known to stimulate axon reflex, neurogenic flare and itch in the skin. In addition, CGRP has been shown to be released in the flare area elicited by histamine iontophoresis [166]. The effect of histamine on cutaneous nerves and flare can be controlled by topical anaesthetics [150] and by nedocromil sodium and loop diuretics, frusemide and bumetadine, drugs which appear to inhibit the $\mathrm{Na}^{+} / \mathrm{K}^{+} / 2 \mathrm{Cl}^{-}$cotransporter in the sensory nerve membranes [206]. Hence, both tryptase and histamine released from mast cells can act together and stimulate surrounding nerves and neurogenic inflammation (Fig. 1), but the regulatory mechanisms are far from complete understanding in chronic skin inflammation.

In addition to neuropeptides, also neurotrophins, such as nerve growth factor (NGF), and its high-affinity receptor (TrkA) have been suggested to play a role in psoriasis, especially in pruritic psoriasis [21, 127], and NGF may be involved in the growth of nerves in the psoriatic lesion. Nevertheless, human mast cells have previously been shown to express NGF and TrkA, and release NGF upon mast cell activation [135, 209]. Therefore, NGF released from mast cells is one possible mediator acting as an autocrine growth factor for mast cells and also interacting with nerves. Whether NGF is actually expressed in mast cells in the psoriatic lesion needs to be clarified. The neuropeptide, $\alpha$-melanocyte-stimulating hormone, evidently acts as an anti-inflammatory mediator and a potent modulator of the immune system [107]. Thus, $\alpha$-melanocyte-stimulating hormone may have potential in the regulation of psoriatic inflammation but this needs to be studied further. Interestingly, $\alpha$-melanocyte-stimulating hormone can sensitively, at picomolar concentrations, activate skin mast cells for histamine release [56].

\section{Mast cells in relation to cells of the immune system in psoriasis}

The modern aspects of the immunopathogenesis of psoriasis have been presented in recent review articles [104, 157].
Evidently, different subsets of $\mathrm{T}$ cells, antigen presenting cells, neutrophils and keratinocytes are all essentially involved in the immunoregulation in psoriasis. It is, however, noteworthy that mast cells can express a range of chemokines, cytokines and cell surface proteins which link them intimately to the innate and acquired immune system $[29,46]$. It has long been known that the psoriatic lesion is characterized by a Th1 type of cell infiltrates [190]. However, after recent discovery of the novel Th17 cell type producing IL-17 and IL-22 it was realized that both T cell types, Th1 and Th17, are present in the psoriatic lesion, and Th17 cells have paramount importance in the lesion development $[105,108,218]$. Similarly to Th1 cells, also Th17 cells are induced to differentiate from naïve $\mathrm{T}$ cells. However, the induction of Th17 cells is regulated by IL- 6 and TGF- $\beta$, and IL-23 is required for the development and maintenance of the Th17 lineage. Nevertheless, numerous other factors have an impact on Th17 cell development, too $[22,218]$. The defective function of regulatory $\mathrm{T}$ cells can also have an impact on the development of psoriatic inflammation since these $T$ cells in psoriatic patients cannot efficiently inhibit effector T cell activity [179].

The close interaction of mast cells with $\mathrm{T}$ cells has been shown in several studies and mast cells can express soluble factors, cell surface molecules and co-stimulatory molecules which can activate different subsets of $\mathrm{T}$ cells as reviewed by Mekori and Metcalfe [116], and Sayed and Brown [160]. In co-cultures of mouse mast cells and $\mathrm{T}$ cells, both cell-cell proximity and soluble factors, especially TNF, can contribute to $\mathrm{T}$ cell proliferation, and mast cells can activate multiple $\mathrm{T}$ cell subsets, such as $\mathrm{CD}^{+}$, $\mathrm{CD}^{+}, \mathrm{Th} 1, \mathrm{Th} 2, \mathrm{Tc} 1, \mathrm{Tc} 2, \gamma \delta \mathrm{TCR}^{+}$and $\mathrm{CD} 4^{+} \mathrm{CD} 2 \mathrm{~L}^{-} \mathrm{T}$ cells [124]. The same group demonstrated later that this mast cell-induced enhancement of $\mathrm{T}$ cell activation is significantly dependent on the secretion of soluble TNF and direct cell-cell interactions between mast cell OX40 ligand and T cell OX40 receptor [125]. Similarly, human mast cells have been shown to activate $\mathrm{T}$ cells in vitro by direct cross-talk between OX40 ligand on mast cells and OX40 receptor on T cells [90]. Mast cells have previously been shown to express another member of the TNF superfamily on the cell membrane, CD30 ligand, that is functional and can activate lymphoma cell lines in vitro [121]. Mast cells can act as antigen-presenting cells to T cells in an MHC class I- and MHC class II-dependent manner in vitro [46, 116, 160], and human mast cells have been shown to express MHC class II and to present staphylococcal superantigens to $\mathrm{CD}^{+}{ }^{+} \mathrm{T}$ cell hybridomas leading to $\mathrm{T}$ cell activation [152]. Furthermore, human cord blood-derived mast cells exposed to different gram-negative and gram-positive bacteria in vitro have been shown to bind and phagocytose several bacteria strains, such as Staphylococcus aureus, leading to death of bacteria and TNF- $\alpha$ secretion from mast 
cells [7]. In addition to antigen presentation, mouse and human mast cells cultured in vitro have been shown to express CD80 and CD86 that are needed as co-stimulatory signals for efficient $T$ cell activation [44, 152]. In fact, human mast cells express a range of different $\mathrm{CD}$ antigens and ICAM-1, VLA-4, Mac-1 and to some extent also LFA1 [47, 77]. The adhesion molecules on mast cells, especially ICAM-1, can interact with $\mathrm{T}$ cells leading to $\mathrm{T}$ cell activation, but on the other hand mast cells can also be activated upon cell-cell contact with activated T cells resulting in enhanced mast cell degranulation, migration and adhesion to extracellular matrix and endothelial cell ligands [12]. In recent experiments with mice, mast cells and their TNF have been reported to enhance antigen- and Th17 celldependent development of a neutrophil-rich inflammatory response in airways [126] suggesting that mast cells can promote Th17 cell-dependent inflammation in vivo. In addition to local actions in the skin previous findings in mice show that as a result of dinitrofluorobenzene-induced contact hypersensitivity mast cells are activated and they migrate to draining lymph nodes wherein they can mediate T cell recruitment [198]. Further support for mast cellinduced lymph node activation and hypertrophy is provided by the study showing that activation of mast cells in mouse footpad by injection of Escherichia coli bacteria or compound 48/80 results in rapid draining of mast cell-derived preformed TNF to lymph nodes wherein it induces hypertrophy and recruitment of circulating T cells [115]. Further, Jawdat et al. [81] have demonstrated that the mast celldependent lymph node activation in mice can be mast cell TNF-dependent in an allergic response or TNF-independent in a response to bacterial peptidoglycan injection.

Different types of professional antigen presenting cells, such as Langerhans cells, macrophages, plasmacytoid dendritic cells and myeloid dendritic cells, have been presented to be essentially involved in the initiation of the psoriatic lesion and regulation of $\mathrm{T}$ cell responses [104, 157]. The juxtaposition of dendritic cells and mast cells in the upper dermis, however, suggests that these cells have to be in close relationship between each other. Indeed, experimental studies have shown that mast cells are capable of stimulating Langerhans cells and dendritic cells. For example, mast cell activation in mouse ear pinna induced by an IgEdependent mechanism or by a bacterial peptidoglycan injection is crucial in the stimulation of Langerhans cell migration to draining lymph nodes [81]. Similarly, mast cells and their TNF are needed for optimal migration of dendritic cells to local lymph nodes after induction of contact hypersensitivity in mouse ear pinna with FITC [180]. One potent mechanism for dendritic cell activation may be via mast cell-derived exosomes. These vesicles from mouse bone marrow-derived mast cells, located in the endocytic pathway and capable of harboring exogenous antigens, have been shown to stimulate and maturate mouse dendritic cells leading to strongly enhanced antigen presenting activity to T cells [172]. In co-cultures of human in vitro-developed mast cells and monocyte-derived dendritic cells, mast cells activated by FceRI cross-linking induced maturation of dendritic cells which in turn polarized naïve $\mathrm{T}$ cells towards the Th2 lineage, an effect largely dependent on secreted histamine and contacts between mast cells and dendritic cells [94]. In fact, histamine has previously been proved effective in dendritic cell maturation and activation. For example, histamine receptor $\mathrm{H} 1$ and $\mathrm{H} 3$ stimulation on dendritic cells results in proinflammatory cytokine production, Th1 priming and increased antigen presenting activity, whereas $\mathrm{H} 2$ stimulation leads to IL-10 induction and Th2 or tolerance priming [3]. Nevertheless, it is currently not known how these interactions between mast cells and antigen presenting cells are actually working in the psoriatic skin or in mouse models of psoriasis. Histamine has also been shown to stimulate human keratinocytes through $\mathrm{H} 1$ receptor for increased expression of IL-6, IL-8, GM-CSF, TNF- $\alpha$, ICAM- 1 and different matrix metalloproteinases, and histamine even augmented the TNF- $\alpha$-induced GMCSF, IL-8 and IL-6 expression [111]. In addition, histamine can augment through $\mathrm{H} 1$ receptor the interferon- $\gamma$-induced expression of MHC class I, ICAM-1, GM-CSF, CCL-5/ RANTES, CCL-2/MCP-1, CCL-20/MIP-3 $\alpha$ and CXCL-10/ IP-10 in human keratinocytes [49].

In addition to the proinflammatory role of mast cells, these cells can also be involved in the induction of tolerance or immunosuppression. For example, mast cells are essentially involved in the induction of regulatory $\mathrm{T}$ celldependent peripheral tolerance in a mouse model of skin allografts, a reaction which appears to be related to the production of IL-9, a mast cell growth and activation factor, from activated regulatory $\mathrm{T}$ cells [106]. In a mouse model of contact hypersensitivity using prolonged monitoring for up to 15 days after challenge, mast cells have been shown, unexpectedly, to be able to limit the inflammatory skin reaction by producing the immunosuppressive cytokine IL10. In the same study, mast cells were also able to attenuate the mouse skin reactions induced by multiple challenges with ultraviolet irradiation for up to 30 days [54]. Furthermore, immunosuppression of mouse skin contact hypersensitivity reaction by ultraviolet irradiation has been reported to be dependent on CXCR4-positive mast cells which migrate from the skin to the $\mathrm{B}$ cell area of draining lymph node as a result of chemoattraction by CXCL-12 (stromal cell-derived factor- $1 \alpha$ ) [15]. In another mouse skin model, mast cells and concomitant IL-10 expression in lymph nodes have been reported to be critical intermediaries in the mosquito bite-induced suppression of delayed-type hypersensitivity reaction [30]. Hence, there are open questions like in which immunological environment mast cells can 
promote inflammation and in which conditions they can suppress it, and how these experimental results can be linked to human skin diseases. Human mast cells have been shown to express IL-10 [79] and therefore this cytokine is one good candidate for mediating immunosuppressive effects of mast cells in some disease states. Interestingly, IL-10 released from human mast cells can inhibit also mast cell function in an autocrine or paracrine fashion [153].

In the psoriatic lesion, mast cells are increased in number but at the same time also the percentage of mast cells showing interferon- $\gamma$ immunoreactivity is significantly increased in the upper dermis when compared with mast cells in the non-lesional psoriatic skin [2] (Table 1), a result which agrees with the well-known findings that psoriatic lesions contain numerous Th1 type cells [190]. In addition, interferon- $\gamma$-positive mast cells in the psoriatic lesion correlate with the psoriasis area and severity index score [2]. In contrast to psoriasis, mast cells in the atopic dermatitis lesions show elevated amounts of IL-4 but are only weakly immunopositive for interferon- $\gamma$ [2, 69]. In addition, IL-4-positive mast cells are significantly associated with the size of allergic skin prick-test wheal reaction and serum total IgE levels [156]. Even though human mast cells have been shown to express IL-6 and TGF- $\beta 1$ [88, 99]; it is, however, not known to what extent mast cells contain these Th17 priming cytokines in the psoriatic skin. Our preliminary results suggest that mast cells contain IL-6 immunoreactivity in the developing psoriatic lesion induced by the tape-stripping technique (Suttle et al., unpublished results) (Fig. 2).

TNF- $\alpha$ has emerged to be one crucial cytokine in the psoriatic inflammation as evidenced by the rapidly expanding clinical use of potent biological drugs targeted towards this cytokine. Interestingly, mast cells are the predominant source of preformed TNF- $\alpha$ in normal skin [194], and along with increased mast cell numbers also TNF- $\alpha$-positive mast cells are increased in number in the lesional psoriatic skin [1]. However, increased TNF- $\alpha$-positive mast cells have been counted in the basal cell carcinoma lesions as well [32]. Even though TNF- $\alpha$ and histamine alone or in combination can activate keratinocytes for the production of proinflammatory factors $[1,111], \mathrm{TNF}-\alpha$ and histamine have also properties which imply a regulatory role in the growth of the epidermis [33, 72]. TNF- $\alpha$ can inhibit the growth of keratinocytes and this effect is enhanced by heparin [63]. In addition, the combination of TNF- $\alpha$ and histamine leads to strongly increased growth inhibition and even cytolysis of normal keratinocytes in vitro [33]. Whether psoriatic keratinocytes are resistant to the growth-inhibitory effect of TNF- $\alpha$, heparin and histamine in different combinations needs to be studied. CD30 ligand is another member of the TNF superfamily expressed functionally in mast cells [121]. Activation of the receptor of CD30 ligand, CD30, on $\mathrm{T}$ cells in vitro leads to interferon- $\gamma$ secretion in Th1 cell clones and IL-4 and IL-5 secretion in Th2 cell clones [8]. In the psoriatic lesion, the percentage of mast cells showing immunoreactivity of CD30 ligand is significantly increased together with increased numbers of CD30-positive cells in the upper dermis. Furthermore, mast cells can be induced by means of reverse signalling through CD30 ligand to express chemokines such as IL- 8, MIP- $1 \alpha$ and MIP- $1 \beta$ [42]. Thus, during the interaction between CD30 ligand on mast cells and CD30 receptor on $\mathrm{T}$ cells both cells are presumably activated in the psoriatic lesion. This is not a specific feature to psoriasis since increased amounts of CD30 ligand have been observed in mast cells in atopic dermatitis as well as in basal cell carcinoma lesions [32, 42]. Based on
Fig. 2 Interleukin-6 is localized to mast cells in the developing psoriatic lesion. The development of the psoriatic lesion, i.e. the Köbner-phenomenon, was induced by the tape-stripping technique (see [61]) and a sequence of skin biopsies was taken. The skin cryosection from a 7-day-old lesion was first stained. a Enzyme-histochemically for mast cell tryptase (red cells). After photographing and dissolving the red azo dye away with Tween 20 the same section was stained; b immunohistochemically using mouse monoclonal anti-IL-6 antibody. Note that almost all tryptase-positive mast cells show IL-6 immunoreactivity. Also endothelial cells and other cells in the papillary dermis display IL-6
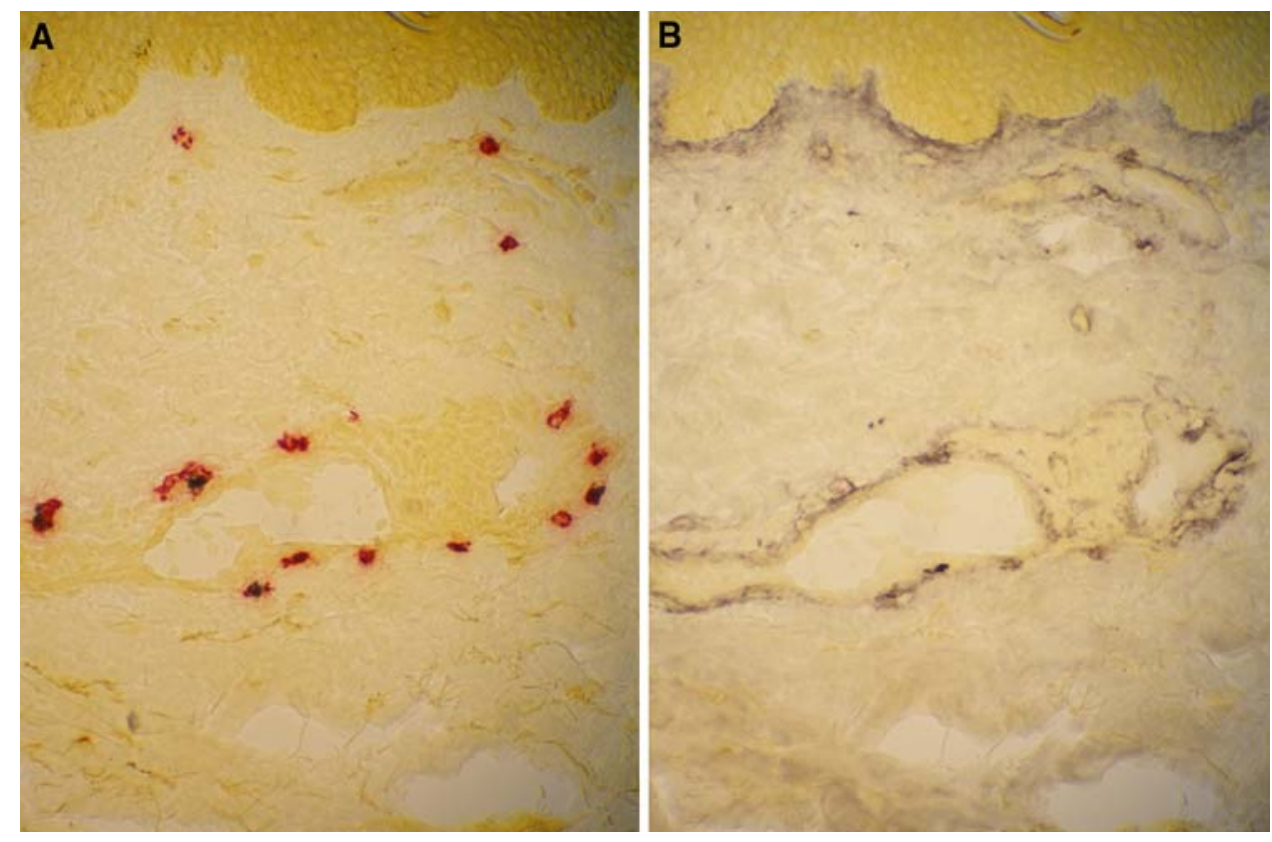
Fig. 3 Interaction between mast cells and $\mathrm{T}$ cells in skin inflammation. Upon activation mast cells can synthesize and release a number of soluble mediators which can stimulate different subsets of T cells leading to proinflammation or in some circumstances to immunosuppression. Mast cells express MHC class I and II molecules which can present either a processed antigen or a superantigen to T cells. In addition, mast cells express costimulatory molecules which are needed for efficient $T$ cell activation. During LFA-1-ICAM-1 interaction or during CD30 ligand-CD30 receptor interaction also mast cells are activated in addition to $\mathrm{T}$ cells

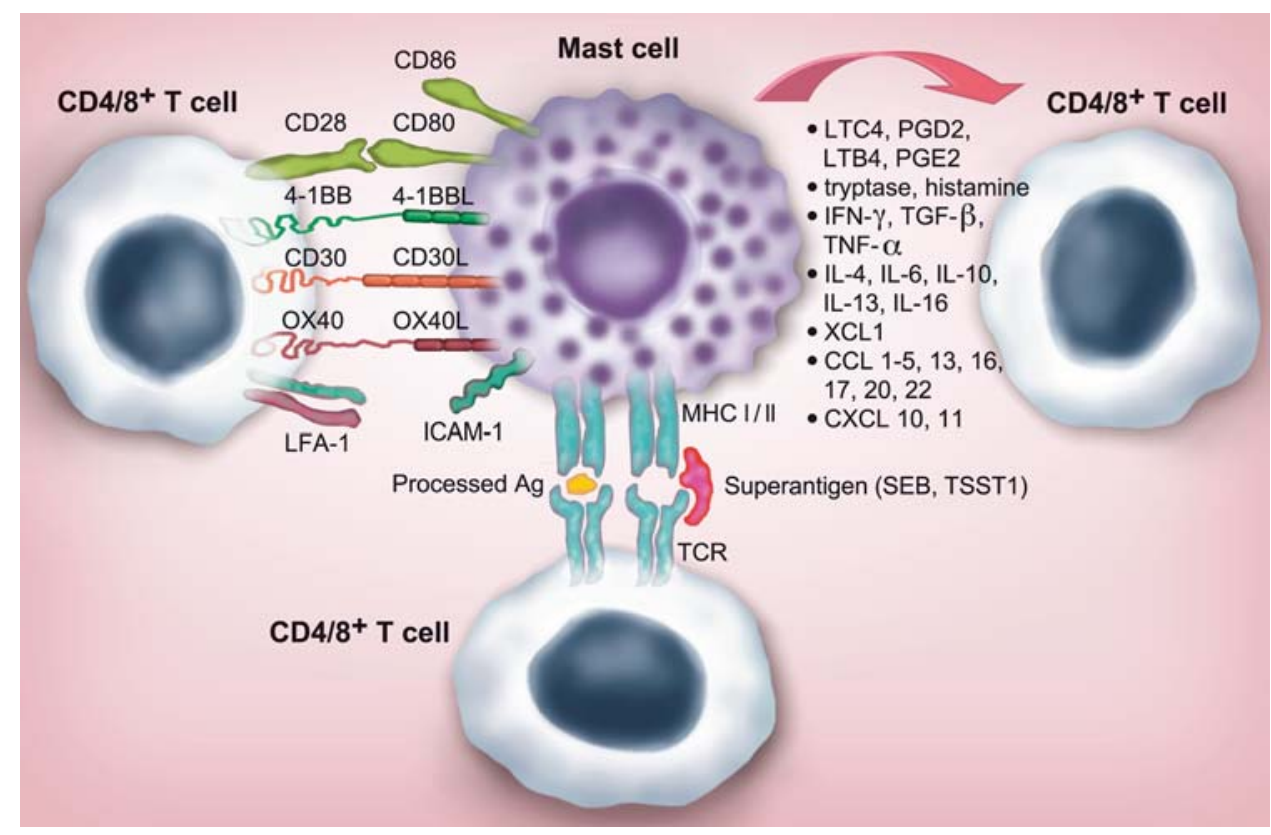

the previous in vitro and in vivo data, mast cells can probably interact with $\mathrm{T}$ cells in the psoriatic lesion with different mechanisms as illustrated in Fig. 3. Mast cells can secrete soluble mediators and express co-stimulatory molecules needed for $\mathrm{T}$ cell recruitment and activation. Also, mast cells can act as antigen presenting cells since they can express MHC class I and II molecules.

\section{Conclusions}

Once dismissed as "allergy cells" the current knowledge now indicates that mast cells have an essential role in the immunopathological mechanisms of chronic inflammatory diseases. Mast cells can be activated by a range of different mechanisms and they can synthesize and release rapidly or secrete slowly potent preformed and newly synthesized mediators as well as express cell surface ligands and receptors, molecules which can be proinflammatory or induce immunosuppression. Mast cells can also recruit the cells of the immune system, such as T cells, neutrophils and eosinophils, to the site of developing skin lesion, and they are able to affect keratinocytes, endothelial cells and sensory nerves. Mast cells can migrate to the draining lymph node and thereby affect distant immune cells, or they can stimulate the maturation of Langerhans cells and dendritic cells and their migration to lymph nodes. These cellular interactions are crucial for the development of skin inflammation, such as in the psoriatic lesion, where mast cells are activated early in the lesion development followed by the increase in $\mathrm{MC}_{\mathrm{TC}}$ mast cell number and in morphological contacts between sensory nerves and mast cells. In addition, mast cells show critical plasticity in the expression of cytokines and other TNF family ligands, a feature which strongly suggests that mast cells are involved in the immunoregulation in psoriasis. In the chronic psoriatic lesion, mast cells accumulated in the upper dermis are in the state of activation and they constantly produce proinflammatory mediators which promote perpetuation of the lesion. Several potent drugs used for the treatment of psoriasis can affect also mast cell activity and/or cell number, such as cyclosporin A, corticosteroids, retinoids and even new biological TNF- $\alpha$ or LFA-1 (CD11a/CD18) blocking drugs. Further studies are needed to clarify in more detail which mediators and cell surface molecules are, in fact, expressed in mast cells in psoriasis compared to other skin diseases and their relation to clinical severity. An important question to be answered is when and how mast cell functions as a proinflammatory cell and when and how as an immunosuppressive cell. It is also possible that mast cells attempt to maintain skin homeostasis by preventing excessive inflammation and epidermal growth but fail in this task. These aspects need to be analyzed also in animal models of psoriasis.

Acknowledgments The authors wish to thank the Marie Curie Mobility Actions for Early Stage Researcher by the sixth framework of the EU commission (project no. 504926), Kuopio University Hospital, Abbott, Finland, and MacNet (Mast Cell Network) funded by Swedish Research Council. Ms Marjukka Aronen is thanked for illustrative artwork of figures.

\section{References}

1. Ackermann L, Harvima IT (1998) Mast cells of psoriatic and atopic dermatitis skin are positive for TNF- $\alpha$ and their degranulation is associated with expression of ICAM-1 in the epidermis. Arch Dermatol Res 290:353-359 
2. Ackermann L, Harvima IT, Pelkonen J, Ritamäki-Salo V, Naukkarinen A, Harvima RJ, Horsmanheimo M (1999) Mast cells in psoriatic skin are strongly positive for interferon-gamma. $\mathrm{Br} \mathrm{J}$ Dermatol 140:624-633

3. Akdis CA, Blaser K (2003) Histamine in the immune regulation of allergic inflammation. J Allergy Clin Immunol 112:15-22

4. Amadesi S, Nie J, Vergnolle N, Cottrell G, Grady EF, Trevisani M, Manni C, Geppetti P, McRoberts JA, Ennes H, Davis JB, Mayer EA, Bunnett NW (2004) Protease-activated receptor 2 sensitizes the capsaicin receptor transient receptor potential vanilloid receptor 1 to induce hyperalgesia. J Neurosci 24:43004312

5. Anand P, Springall DR, Blank MA, Sellu D, Polak JM, Bloom SR (1991) Neuropeptides in skin disease: increased VIP in eczema and psoriasis but not axillary hyperhidrosis. Br J Dermatol 124:547-549

6. Arck PC, Slominski A, Theoharides TC, Peters EMJ, Paus R (2006) Neuroimmunology of stress: skin takes center stage. J Invest Dermatol 126:1697-1704

7. Arock M, Ross E, Lai-Kuen R, Averlant G, Gao Z, Abraham SM (1998) Phagocytic and tumor necrosis factor alpha response of human mast cells following exposure to gram-negative and gram-positive bacteria. Infect Immun 66:6030-6034

8. Bengtsson Å, Scheynius A, Avila-Cariño J (2000) Crosslinking of CD30 on activated human Th clones enhances their cytokine production and downregulates the CD30 expression. Scand J Immunol 52:595-601

9. Bernstein JE, Parish LC, Rapaport M, Rosenbaum MM, Roenigk HH (1986) Effects of topically applied capsaicin on moderate and severe psoriasis vulgaris. J Am Acad Dermatol 15:504-507

10. Blair RJ, Meng H, Marchese MJ, Ren S, Schwartz LB, Tonnesen MG, Gruber BL (1997) Human mast cells stimulate vascular tube formation: tryptase is a novel, potent angiogenic factor. J Clin Invest 99:2691-2700

11. Bolton LL, Montagna W (1993) Mast cells in human ulcers. Am J Dermatopathol 15:133-138

12. Brill A, Baram D, Sela U, Salamon P, Mekori YA, Hershkoviz R (2004) Induction of mast cell interactions with blood vessel wall components by direct contact with intact $\mathrm{T}$ cells or T cell membranes in vitro. Clin Exp Allergy 34:1725-1731

13. Brody I (1984) Mast cell degranulation in the evolution of acute eruptive guttate psoriasis vulgaris. J Invest Dermatol 82:460-464

14. Buddenkotte J, Stroh C, Engels IH, Moormann C, Shpacovitch VM, Seeliger S, Vergnolle N, Vestweber D, Luger TA, SchulzeOsthoff K, Steinhoff M (2005) Agonists of proteinase-activated receptor-2 stimulate upregulation of intercellular cell adhesion molecule-1 in primary human keratinocytes via activation of NFkappa B. J Invest Dermatol 124:38-45

15. Byrne SN, Limón-Flores AL, Ullrich SE (2008) Mast cell migration from the skin to the draining lymph nodes upon ultraviolet irradiation represents a key step in the induction of immune suppression. J Immunol 180:4648-4655

16. Cairns JA, Walls AF (1996) Mast cell tryptase is a mitogen for epithelial cells. Stimulation of IL-8 production and intercellular adhesion molecule-1 expression. J Immunol 156:275-283

17. Cao J, Cetrulo CL, Theoharides TC (2006) Corticotropin-releasing hormone induces vascular endothelial growth factor release from human mast cells via the cAMP/protein kinase A/p38 mitogenactivated protein kinase pathway. Mol Pharmacol 69:998-1006

18. Caughey GH, Leidig F, Viro NF, Nadel JA (1988) Substance P and vasoactive intestinal peptide degradation by mast cell tryptase and chymase. J Pharmacol Exp Ther 244:133-137

19. Caughey GH (2001) New developments in the genetics and activation of mast cell proteases. Mol Immunol 38:1353-1357

20. Caughey GH (2007) Mast cell tryptases and chymases in inflammation and host defense. Immunol Rev 217:141-154
21. Chang S-E, Han S-S, Jung H-J, Choi J-H (2007) Neuropeptides and their receptors in psoriatic skin in relation to pruritus. $\mathrm{Br} \mathbf{J}$ Dermatol 156:1272-1277

22. Chen Z, Laurence A, O'Shea JJ (2007) Signal transduction pathways and transcriptional regulation in the control of Th17 differentiation. Semin Immunol 19(6):400-408

23. Church MK, Lowman MA, Rees PH, Benyon RC (1989) Mast cells, neuropeptides and inflammation. Agents Actions 27:8-16

24. Compton SJ, Cairns JA, Holgate ST, Walls AF (1998) The role of mast cell tryptase in regulating endothelial cell proliferation, cytokine release, and adhesion molecule expression: tryptase induces expression of mRNA for IL- $1 \beta$ and IL- 8 and stimulates the selective release of IL-8 from human umbilical vein endothelial cells. J Immunol 161:1939-1946

25. Compton SJ, Cairns JA, Holgate ST, Walls AF (2000) Human mast cell tryptase stimulates the release of an IL-8-dependent neutrophil chemotactic activity from human umbilical vein endothelial cells (HUVEC). Clin Exp Immunol 121:31-36

26. Costa JJ, Demetri GD, Harrist TJ, Dvorak AM, Hayes DF, Merica EA, Menchaca DM, Gringeri AJ, Schwartz LB, Galli SJ (1996) Recombinant human stem cell factor (kit ligand) promotes human mast cell and melanocyte hyperplasia and functional activation in vivo. J Exp Med 183:2681-2686

27. Cox AJ (1977) Mast cells in psoriasis. In: Cox AJ, Farber EM (eds) Psoriasis, proceedings of the second international symposium, Stanford University, 1976. Yorke Medical Books, New York, pp 36-43

28. Cui P, Tani K, Kitamura H, Okumura Y, Yano M, Inui D, Tamaki T, Sone S, Kido H (2001) A novel bioactive 31-amino acid endothelin-1 is a potent chemotactic peptide for human neutrophils and monocytes. J Leukoc Biol 70:306-312

29. Dawicki W, Marshall JS (2007) New and emerging roles for mast cells in host defence. Curr Opin Immunol 19:31-38

30. Depinay N, Hacini F, Beghdadi W, Peronet R, Mécheri S (2006) Mast cell-dependent down-regulation of antigen-specific immune responses by mosquito bites. J Immunol 176:4141-4146

31. Diaconu N-C, Kaminska R, Naukkarinen A, Harvima RJ, Harvima IT (2007) The increase in tryptase- and chymase-positive mast cells is associated with partial inactivation of chymase and increase in protease inhibitors in basal cell carcinoma. J Eur Acad Dermatol Venereol 21:908-915

32. Diaconu N-C, Kaminska R, Naukkarinen A, Harvima RJ, Nilsson G, Harvima IT (2007) Increase in CD30 ligand/CD153 and TNF- $\alpha$ expressing mast cells in basal cell carcinoma. Cancer Immunol Imunother 56:1407-1415

33. Diaconu N-C, Rummukainen J, Mättö M, Naukkarinen A, Harvima RJ, Pelkonen J, Harvima IT (2008) Cervical squamous carcinoma cells are resistant to the combined action of tumor necrosis factor- $\alpha$ and histamine whereas normal keratinocytes undergo cytolysis. BMC Cancer 8:46

34. Dvorak AM, Kissell S (1991) Granule changes of human skin mast cells characteristic of piecemeal degranulation and associated with recovery during wound healing in situ. J Leukoc Biol 49:197-210

35. Dvorak AM, Costa JJ, Monahan-Earley RA, Fox P, Galli SJ (1998) Ultrastructural analysis of human skin biopsy specimens from patients receiving recombinant human stem cell factor: subcutaneous injection of rhSCF induces mast cell degranulation and granulocyte recruitment at the injection site. J Allergy Clin Immunol 101:793-806

36. Eedy DJ, Johnston CF, Shaw C, Buchanan KD (1991) Neuropeptides in psoriasis: an immunocytochemical and radioimmunoassay study. J Invest Dermatol 96:434-438

37. Eichelberg D, Schmutzler W (1988) Synthetic retinoids inhibit histamine release from isolated human mast cells. Arch Dermatol Res 280:155-157 
38. el-Lati SG, Dahinden CA, Church MK (1994) Complement peptides C3a- and C5a-induced mediator release from dissociated human skin mast cells. J Invest Dermatol 102:803-806

39. Fajardo I, Pejler G (2003) Human mast cell $\beta$-tryptase is a gelatinase. J Immunol 171:1493-1499

40. Farber EM, Lanigan SW, Boer J (1990) The role of cutaneous sensory nerves in the maintenance of psoriasis. Int $\mathrm{J}$ Dermatol 29:418-420

41. Finotto S, Mekori YA, Metcalfe DD (1997) Glucocorticoids decrease tissue mast cell number by reducing the production of the c-kit ligand, stem cell factor, by resident cells. J Clin Invest 99:1721-1728

42. Fischer M, Harvima IT, Carvalho RFS, Möller C, Naukkarinen A, Enblad G, Nilsson G (2006) Mast cell CD30 ligand is up-regulated in cutaneous inflammations and mediates degranulationindependent chemokine secretion. J Clin Invest 116:2748-2756

43. Franconi GM, Graf PD, Lazarus SC, Nadel JA, Caughey GH (1989) Mast cell tryptase and chymase reverse airway smooth muscle relaxation induced by vasoactive intestinal peptide in the Ferret. J Pharmacol Exp Ther 248:947-951

44. Frandji P, Tkaczyk C, Oskeritzian C, David B, Desaymard C, Mécheri S (1996) Exogenous and endogenous antigens are differentially presented by mast cells to CD4+ T lymphocytes. Eur J Immunol 26:2517-2528

45. Frenz AM, Gibbs BF, Pearce FL (1997) The effect of recombinant stem cell factor on human skin and lung mast cells and basophil leukocytes. Inflamm Res 46:35-39

46. Galli SJ, Nakae S, Tsai M (2005) Mast cells in the development of adaptive immune responses. Nat Immunol 6:135-142

47. Ghannadan M, Baghestanian M, Wimazal F, Eisenmenger M, Latal D, Kargül G, Walchshofer S, Sillaber C, Lechner K, Valent $P$ (1998) Phenotypic characterization of human skin mast cells by combined staining with toluidine blue and CD antibodies. J Invest Dermatol 111:689-695

48. Gibbs BF, Wierecky J, Welker P, Henz BM, Wolff HH, Grabbe J (2001) Human skin mast cells rapidly release preformed and newly generated TNF- $\alpha$ and IL- 8 following stimulation with anti-IgE and other secretagogues. Exp Dermatol 10:312-320

49. Giustizieri ML, Albanesi C, Fluhr J, Gisondi P, Norgauer J, Girolomoni G (2004) H1 histamine receptor mediates inflammatory responses in human keratinocytes. J Allergy Clin Immunol 114:1176-1182

50. Glinski W, Glinska-Ferenz M, Pierozynska-Dubowska M (1991) Neurogenic inflammation induced by capsaicin in patients with psoriasis. Acta Derm Venereol (Stockh) 71:51-54

51. Goldstein SM, Leong J, Bunnett NW (1991) Human mast cell proteases hydrolyze neurotensin, kinetensin and Leu ${ }^{5}$-enkephalin. Peptides 12:995-1000

52. Goldstein SM, Leong J, Schwartz LB, Cooke D (1992) Protease composition of exocytosed human skin mast cell protease-proteoglycan complexes. Tryptase resides in a complex distinct from chymase and carboxypeptidase. J Immunol 148:2475-2482

53. Green RM, Cordero A, Winkelmann RK (1977) Epidermal mast cells. Arch Dermatol 113:166-169

54. Grimbaldeston MA, Nakae S, Kalesnikoff J, Tsai M, Galli SJ (2007) Mast cell-derived interleukin 10 limits skin pathology in contact dermatitis and chronic irradiation with ultraviolet B. Nat Immunol 8:1095-1104

55. Gruber BL, Marchese MJ, Suzuki K, Schwartz LB, Okada Y, Nagase H, Ramamurthy NS (1989) Synovial procollagenase activation by human mast cell tryptase: dependence upon matrix metalloproteinase 3 activation. J Clin Invest 84:1657-1662

56. Grützkau A, Henz BM, Kirchhof L, Luger T, Artuc M (2000) $\alpha$ Melanocyte stimulating hormone acts as a selective inducer of secretory functions in human mast cells. Biochem Biophys Res Commun 278:14-19
57. Hallgren J, Estrada S, Karlson U, Alving K, Pejler G (2001) Heparin antagonists are potent inhibitors of mast cell tryptase. Biochemistry 40:7342-7349

58. Harvima IT, Harvima RJ, Eloranta TO, Fräki JE (1988) The allosteric effect of salt on human mast cell tryptase. Biochim Biophys Acta 956:133-139

59. Harvima IT, Naukkarinen A, Harvima RJ, Horsmanheimo M (1989) Enzyme- and immunohistochemical localization of mast cell tryptase in psoriatic skin. Arch Dermatol Res 281:387-391

60. Harvima IT, Naukkarinen A, Harvima RJ, Aalto M-L, Neittaanmäki H, Horsmanheimo M (1990) Quantitative enzyme-histochemical analysis of tryptase- and chymase-containing mast cells in psoriatic skin. Arch Dermatol Res 282:428-433

61. Harvima IT, Naukkarinen A, Paukkonen K, Harvima RJ, Aalto M-L, Schwartz LB, Horsmanheimo M (1993) Mast cell tryptase and chymase in developing and mature psoriatic lesions. Arch Dermatol Res 285:184-192

62. Harvima IT, Haapanen L, Ackermann L, Naukkarinen A, Harvima RJ, Horsmanheimo M (1999) Decreased chymase activity is associated with increased levels of protease inhibitors in mast cells of psoriatic lesions. Acta Derm Venereol (Stockh) 79:98 104

63. Harvima IT, Lappalainen K, Hirvonen M-R, Mättö M, Kivinen PK, Hyttinen M, Pelkonen J, Naukkarinen A (2004) Heparin modulates the growth and adherence and augments the growthinhibitory action of TNF- $\alpha$ on cultured human keratinocytes. J Cell Biochem 92:372-386

64. Harvima RJ, Harvima IT, Dull D, Dunder UK, Schwartz LB (1999) Identification and characterization of multiple forms of tryptase from human mast cells. Arch Dermatol Res 291:73-80

65. He S, Peng Q, Walls AF (1997) Potent induction of a neutrophil and eosinophil-rich infiltrate in vivo by human mast cell tryptase: selective enhancement of eosinophil recruitment by histamine. J Immunol 159:6216-6225

66. He S, Walls AF (1998) Human mast cell chymase induces the accumulation of neutrophils, eosinophils and other inflammatory cells in vivo. Br J Pharmacol 125:1491-1500

67. Hjertson M, Kivinen PK, Dimberg L, Nilsson K, Harvima IT, Nilsson G (2003) Retinoic acid inhibits in vitro development of mast cells but has no marked effect on mature human skin tryptase- and chymase-positive mast cells. J Invest Dermatol 120:239-245

68. Holm M, Kvistgaard H, Dahl C, Andersen HB, Hansen TK, Schiøtz PO, Junker S (2006) Modulation of chemokine gene expression in $\mathrm{CD} 133^{+}$cord blood-derived human mast cells by cyclosporin A and dexamethasone. Scand J Immunol 64:571-579

69. Horsmanheimo L, Harvima IT, Järvikallio A, Harvima RJ, Naukkarinen A, Horsmanheimo M (1994) Mast cells are one major source of interleukin-4 in atopic dermatitis. Br J Dermatol 131:348-353

70. Hou L, Kapas S, Cruchley AT, Macey MG, Harriott P, Chinni C, Stone SR (1998) Immunolocalization of protease-activated receptor-2 in skin: receptor activation stimulates interleukin-8 secretion by keratinocytes in vitro. Immunology 94:356-362

71. Huttunen M, Harvima IT, Ackermann L, Harvima RJ, Naukkarinen A, Horsmanheimo M (1996) Neuropeptide- and capsaicininduced histamine release in skin monitored with the microdialysis technique. Acta Derm Venereol (Stockh) 76:205-209

72. Huttunen M, Hyttinen M, Nilsson G, Butterfield JH, Horsmanheimo M, Harvima IT (2001) Inhibition of keratinocyte growth in cell culture and whole skin culture by mast cell mediators. Exp Dermatol 10:184-192

73. Huttunen M, Naukkarinen A, Horsmanheimo M, Harvima IT (2002) Transient production of stem cell factor in dermal cells but increasing expression of Kit receptor in mast cells during normal wound healing. Arch Dermatol Res 294:324-330 
74. Huttunen M, Harvima IT (2005) Mast cell tryptase and chymase in chronic leg ulcers: chymase is potentially destructive to epithelium and is controlled by proteinase inhibitors. Br J Dermatol 152:1149-1160

75. Iddamalgoda A, Le QT, Ito K, Tanaka K, Kojima H, Kido H (2008) Mast cell tryptase and photoaging: possible involvement in the degradation of extra cellular matrix and basement membrane proteins. Arch Dermatol Res 300(Suppl 1):69-76

76. Ide H, Itoh H, Yoshida E, Kobayashi T, Tomita M, Maruyama H, Osada Y, Nakahata T, Nawa Y (1999) Immunohistochemical demonstration of inter- $\alpha$-trypsin inhibitor light chain (bikunin) in human mast cells. Cell Tissue Res 297:149-154

77. Inamura H, Kurosawa M, Kuwasaki T, Kamada Y, Kayaba H, Chihara J (2001) Expression of adhesion molecules on cordblood-derived, cultured human mast cells and effect of dexamethasone on intercellular adhesion molecule-1 expression on the mast cells treated by phorbol myristate acetate. Allergy 56:672-678

78. Irani A-MA, Bradford TR, Kepley CL, Schechter NM, Schwartz $\mathrm{LB}$ (1989) Detection of $\mathrm{MC}_{\mathrm{T}}$ and $\mathrm{MC}_{\mathrm{TC}}$ types of human mast cells by immunohistochemistry using new monoclonal anti-tryptase and anti-chymase antibodies. J Histochem Cytochem 37:1509-1515

79. Ishizuka T, Okayama Y, Kobayashi H, Mori M (1999) Interleukin-10 is localized to and released by human lung mast cells. Clin Exp Allergy 29:1424-1432

80. Iversen O-J, Lysvand H, Jacobsen T, Bergh K, Lie BA (1995) The psoriasis-associated antigen, pso p27, is expressed by tryptase-positive cells in psoriatic lesions. Arch Dermatol Res 287:503-505

81. Jawdat DM, Rowden G, Marshall JS (2006) Mast cells have a pivotal role in TNF-independent lymph node hypertrophy and the mobilization of Langerhans cells in response to bacterial peptidoglycan. J Immunol 177:1755-1762

82. Juremalm M, Hjertson M, Olsson N, Harvima I, Nilsson K, Nilsson G (2000) The chemokine receptor CXCR4 is expressed within the mast cell lineage and its ligand stromal cell-derived factor$1 \alpha$ acts as a mast cell chemotaxin. Eur J Immunol 30:3614-3622

83. Juremalm M, Nilsson G (2005) Chemokine receptor expression by mast cells. Chem Immunol Allergy 87:130-144

84. Järvikallio A, Harvima IT, Naukkarinen A (2003) Mast cells, nerves and neuropeptides in atopic dermatitis and nummular eczema. Arch Dermatol Res 295:2-7

85. Kambe N, Kambe M, Kochan JP, Schwartz LB (2001) Human skin-derived mast cells can proliferate while retaining their characteristic functional and protease phenotypes. Blood 97:20452052

86. Kaminska R, Harvima IT, Naukkarinen A, Nilsson G, Horsmanheimo M (1996) Alterations in mast cell proteinases and protease inhibitors in the progress of cutaneous herpes zoster infection. $\mathrm{J}$ Pathol 180:434-440

87. Kaminska R, Helisalmi P, Harvima RJ, Naukkarinen A, Horsmanheimo M, Harvima IT (1999) Focal dermal-epidermal separation and fibronectin cleavage in basement membrane by human mast cell tryptase. J Invest Dermatol 113:567-573

88. Kanbe N, Kurosawa M, Nagata H, Saitoh H, Miyachi Y (1999) Cord blood-derived human cultured mast cells produce transforming growth factor $\beta_{1}$. Clin Exp Allergy 29:105-113

89. Kanbe N, Kurosawa M, Miyachi Y, Kanbe M, Saitoh H, Matsuda H (2000) Nerve growth factor prevents apoptosis of cord bloodderived human cultured mast cells synergistically with stem cell factor. Clin Exp Allergy 30:1113-1120

90. Kashiwakura J, Yokoi H, Saito H, Okayama Y (2004) T cell proliferation by direct cross-talk between OX40 ligand on human mast cells and OX40 on human T cells: comparison of gene expression profiles between human tonsillar and lung-cultured mast cells. J Immunol 173:5247-5257
91. Kinoshita M, Okada M, Hara M, Furukawa Y, Matsumori A (2005) Mast cell tryptase in mast cell granules enhances MCP-1 and interleukin- 8 production in human endothelial cells. Arterioscler Thromb Vasc Biol 25:1858-1863

92. Kinoshita T, Koike K, Mwamtemi HH, Ito S, Ishida S, Nakazawa Y, Kurokawa Y, Sakashita K, Higuchi T, Takeuchi K, Sawai N, Shiohara M, Kamijo T, Kawa S, Yamashita T, Komiyama A (2000) Retinoic acid is a negative regulator for the differentiation of cord blood-derived human mast cell progenitors. Blood 95:2821-2828

93. Kirshenbaum AS, Goff JP, Kessler SW, Mican JM, Zsebo KM, Metcalfe DD (1992) Effect of IL-3 and stem cell factor on the appearance of human basophils and mast cells from CD34 ${ }^{+}$pluripotent progenitor cells. J Immunol 148:772-777

94. Kitawaki T, Kadowaki N, Sugimoto N, Kambe N, Hori T, Miyachi Y, Nakahata T, Uchiyama T (2006) IgE-activated mast cells in combination with pro-inflammatory factors induce $\mathrm{T}_{\mathrm{h}} 2$-promoting dendritic cells. Int Immunol 18:1789-1799

95. Kivinen PK, Kaminska R, Naukkarinen A, Harvima RJ, Horsmanheimo M, Harvima IT (2001) Release of soluble tryptase but only minor amounts of chymase activity from cutaneous mast cells. Exp Dermatol 10:246-255

96. Kivinen PK, Nilsson G, Naukkarinen A, Harvima IT (2003) Mast cell survival and apoptosis in organ-cultured human skin. Exp Dermatol 12:53-60

97. Krogstad AL, Lönnroth P, Larson G, Wallin BG (1997) Increased interstitial histamine concentration in the psoriatic plaque. J Invest Dermatol 109:632-635

98. Krogstad AL, Lönnroth P, Larson G, Wallin BG (1998) Nerveinduced histamine release is of little importance in psoriatic skin. Br J Dermatol 139:403-409

99. Krüger-Krasagakes S, Möller A, Kolde G, Lippert U, Weber M, Henz BM (1996) Production of interleukin-6 by human mast cells and basophilic cells. J Invest Dermatol 106:75-79

100. Kulka M, Sheen CH, Tancowny BP, Grammer LC, Schleimer RP (2008) Neuropeptides activate human mast cell degranulation and chemokine production. Immunology 123:398-410

101. Li T, He S (2006) Induction of IL-6 release from human T cells by PAR-1 and PAR-2 agonists. Immunol Cell Biol 84:461-466

102. Lohi J, Harvima I, Keski-Oja J (1992) Pericellular substrates of human mast cell tryptase: 72, 000 dalton gelatinase and fibronectin. J Cell Biochem 50:337-349

103. Longley BJ, Tyrrell L, Ma Y, Williams DA, Halaban R, Langley K, Lu HS, Schechter NM (1997) Chymase cleavage of stem cell factor yields a bioactive, soluble product. Proc Natl Acad Sci (USA) 94:9017-9021

104. Lowes MA, Bowcock AM, Krueger JG (2007) Pathogenesis and therapy of psoriasis. Nature 445:866-873

105. Lowes MA, Kikuchi T, Fuentes-Duculan J, Cardinale I, Zaba LC, Haider AS, Bowman EP, Krueger JG (2008) Psoriasis vulgaris lesions contain discrete populations of Th1 and Th17 cells. J Invest Dermatol 128:1207-1211

106. Lu L-F, Lind EF, Gondek DC, Bennett KA, Gleeson MW, PinoLagos K, Scott ZA, Coyle AJ, Reed JL, van Snick J, Strom TB, Zheng XX, Noelle RJ (2006) Mast cells are essential intermediaries in regulatory T-cell tolerance. Nature 442:997-1002

107. Luger TA, Brzoska T (2007) Alpha-MSH related peptides: a new class of anti-inflammatory and immunomodulating drugs. Ann Rheum Dis 66(suppl 3):iii52-iii55

108. Ma HL, Liang S, Li J, Napierata L, Brown T, Benoit S, Senices M, Gill D, Dunussi-Joannopoulos K, Collins M, Nickerson-Nutter C, Fouser LA, Young DA (2008) IL-22 is required for Th17 cell-mediated pathology in a mouse model of psoriasis-like skin inflammation. J Clin Invest 118:597-607

109. Malamud V, Vaaknin A, Abramsky O, Mor M, Burgess LE, BenYehudah A, Lorberboum-Galski H (2003) Tryptase activates 
peripheral blood mononuclear cells causing the synthesis and release of TNF- $\alpha$, IL- 6 and IL- $1 \beta$ : possible relevance to multiple sclerosis. J Neuroimmunol 138:115-122

110. Marone G, Triggiani M, Cirillo R, Giacummo A, Siri L, Condorelli M (1988) Cyclosporin A inhibits the release of histamine and peptide leukotriene $\mathrm{C}_{4}$ from human lung mast cells. Ric Clin Lab 18:53-59

111. Matsubara M, Tamura T, Ohmori K, Hasegawa K (2005) Histamine $\mathrm{H} 1$ receptor antagonist blocks histamine-induced proinflammatory cytokine production through inhibition of $\mathrm{Ca}^{2+}$ dependent protein kinase $\mathrm{C}$, Raf/MEK/ERK and IKK/I $\kappa \mathrm{B} / \mathrm{NF}-$ $\kappa \mathrm{B}$ signal cascades. Biochem Pharmacol 69:433-449

112. Matsuzawa S, Sakashita K, Kinoshita T, Ito S, Yamashita T, Koike K (2003) IL-9 enhances the growth of human mast cell progenitors under stimulation with stem cell factor. J Immunol 170:3461-3467

113. Maurer M, Lopez Kostka S, Siebenhaar F, Moelle K, Metz M, Knop J, von Stebut E (2006) Skin mast cells control T cell-dependent host defense in Leishmania major infections. FASEB J 20:2460-2467

114. McEuen AR, Gaça MDA, Buckley MG, He S, Gore MG, Walls AF (1998) Two distinct forms of human mast cell chymase: differences in affinity for heparin and in distribution in skin, heart, and other tissues. Eur J Biochem 256:461-470

115. McLachlan JB, Hart JP, Pizzo SV, Shelburne CP, Staats HF, Gunn MD, Abraham SN (2003) Mast cell-derived tumor necrosis factor induces hypertrophy of draining lymph nodes during infection. Nat Immunol 4:1199-1205

116. Mekori YA, Metcalfe DD (1999) Mast cell-T cell interactions. J Allergy Clin Immunol 104:517-523

117. Metz M, Piliponsky AM, Chen C-C, Lammel V, Åbrink M, Pejler G, Tsai M, Galli SJ (2006) Mast cells can enhance resistance to snake and honeybee venoms. Science 313:526-530

118. Mierke CT, Ballmaier M, Werner U, Manns MP, Welte K, Bischoff SC (2000) Human endothelial cells regulate survival and proliferation of human mast cells. J Exp Med 192:801-811

119. Min HK, Kambe N, Schwartz LB (2001) Human mouse mast cell protease 7-like tryptase genes are pseudogenes. J Allergy Clin Immunol 107:315-321

120. Mizutani H, Schechter NM, Lazarus G, Black RA, Kupper TS (1991) Rapid and specific conversion of precursor interleukin $1 \beta$ (IL-1 $\beta$ ) to an active IL-1 species by human mast cell chymase. J Exp Med 174:821-825

121. Molin D, Fischer M, Xiang Z, Larsson U, Harvima I, Venge P, Nilsson K, Sundström C, Enblad G, Nilsson G (2001) Mast cells express functional CD30 ligand and are the predominant CD30Lpositive cells in Hodgkin's disease. Br J Haematol 114:616-623

122. Moormann C, Artuc M, Pohl E, Varga G, Buddenkotte J, Vergnolle N, Brehler R, Henz BM, Schneider SW, Luger TA, Steinhoff M (2006) Functional characterization and expression analysis of the proteinase-activated receptor- 2 in human cutaneous mast cells. J Invest Dermatol 126:746-755

123. Möller C, Alfredsson J, Engström M, Wootz H, Xiang Z, Lennartsson J, Jönsson JI, Nilsson G (2005) Stem cell factor promotes mast cell survival via inactivation of FOXO3a-mediated transcriptional induction and MEK-regulated phosphorylation of the proapoptotic protein Bim. Blood 106:1330-1336

124. Nakae S, Suto H, Kakurai M, Sedgwick JD, Tsai M, Galli SJ (2005) Mast cells enhance T cell activation: importance of mast cell-derived TNF. Proc Natl Acad Sci USA 102:6467-6472

125. Nakae S, Suto H, Iikura M, Kakurai M, Sedgwick JD, Tsai M, Galli SJ (2006) Mast cells enhance T cell activation: importance of mast cell costimulatory molecules and secreted TNF. J Immunol 176:2238-2248

126. Nakae S, Suto H, Berry GJ, Galli SJ (2008) Mast cell-derived TNF can promote Th17 cell-dependent neutrophil recruitment in ovalbumin-challenged OTII mice. Blood 109:3640-3648
127. Nakamura M, Toyoda M, Morohashi M (2003) Pruritogenic mediators in psoriasis: comparative evaluation of itch-associated cutaneous factors. Br J Dermatol 149:718-730

128. Naukkarinen A, Nickoloff BJ, Farber EM (1989) Quantification of cutaneous sensory nerves and their substance P content in psoriasis. J Invest Dermatol 92:126-129

129. Naukkarinen A, Harvima IT, Aalto M-L, Harvima RJ, Horsmanheimo M (1991) Quantitative analysis of contact sites between mast cells and sensory nerves in cutaneous psoriasis and lichen planus based on a histochemical double staining technique. Arch Dermatol Res 283:433-437

130. Naukkarinen A, Harvima I, Paukkonen K, Aalto M-L, Horsmanheimo M (1993) Immunohistochemical analysis of sensory nerves and neuropeptides, and their contacts with mast cells in developing and mature psoriatic lesions. Arch Dermatol Res 285:341-346

131. Naukkarinen A, Järvikallio A, Lakkakorpi J, Harvima IT, Harvima RJ, Horsmanheimo M (1996) Quantitative histochemical analysis of mast cells and sensory nerves in psoriatic skin. J Pathol 180:200-205

132. Nilsson G, Butterfield JH, Nilsson K, Siegbahn A (1994) Stem cell factor is a chemotactic factor for human mast cells. J Immunol 153:3717-3723

133. Nilsson G, Miettinen U, Ishizaka T, Ashman LK, Irani AM, Schwartz LB (1994) Interleukin-4 inhibits the expression of Kit and tryptase during stem cell factor-dependent development of human mast cells from fetal liver cells. Blood 84:1519-1527

134. Nilsson G, Blom T, Harvima I, Kusche-Gullberg M, Nilsson K (1996) Stem cell factor-dependent human cord blood derived mast cells express $\alpha$ - and $\beta$-tryptase, heparin and chondroitin sulphate. Immunology 88:308-314

135. Nilsson G, Forsberg-Nilsson K, Xiang Z, Hallböök F, Nilsson K, Metcalfe DD (1997) Human mast cells express functional TrkA and are a source of nerve growth factor. Eur J Immunol 27:22952301

136. Novelli M, Savoia P, Fierro MT, Verrone A, Quaglino P, Bernengo MG (1996) Keratinocytes express dipeptidyl-peptidase IV (CD26) in benign and malignant skin diseases. Br J Dermatol 134:1052-1056

137. Okayama Y, Kirshenbaum AS, Metcalfe DD (2000) Expression of a functional high-affinity IgG receptor, $\mathrm{Fc} \gamma \mathrm{RI}$, on human mast cells: up-regulation by IFN- $\gamma$. J Immunol 164:4332-4339

138. Okumura K, Takai S, Muramatsu M, Katayama S, Sakaguchi M, Kishi K, Jin D, Miyazaki M (2004) Human chymase degrades human fibronectin. Clin Chim Acta 347:223-225

139. Olsson N, Piek E, ten Dijke P, Nilsson G (2000) Human mast cell migration in response to members of the transforming growth factor- $\beta$ family. J Leukoc Biol 67:350-356

140. Omoto Y, Tokime K, Yamanaka K, Habe K, Morioka T, Kurokawa I, Tsutsui H, Yamanishi K, Nakanishi K, Mizutani H (2006) Human mast cell chymase cleaves pro-IL-18 and generates a novel and biologically active IL-18 fragment. J Immunol 177:8315-8319

141. Oran A, Marshall JS, Kondo S, Paglia D, McKenzie RC (1997) Cyclosporin inhibits intercellular adhesion molecule-1 expression and reduces mast cell numbers in the asebia mouse model of chronic skin inflammation. Br J Dermatol 136:519-526

142. Pang L, Nie M, Corbett L, Sutcliffe A, Knox AJ (2006) Mast cell $\beta$-tryptase selectively cleaves eotaxin and RANTES and abrogates their eosinophil chemotactic activities. J Immunol 176:3788-3795

143. Pavlovic S, Daniltchenko M, Tobin DJ, Hagen E, Hunt SP, Klapp BF, Arck PC, Peters EMJ (2008) Further exploring the brain-skin connection: stress worsens dermatitis via substance P-dependent neurogenic inflammation in mice. J Invest Dermatol 128:434 446 
144. Pereira PJB, Bergner A, Macedo-Ribeiro S, Huber R, Matschiner $\mathrm{G}$, Fritz H, Sommerhoff CP, Bode W (1998) Human $\beta$-tryptase is a ring-like tetramer with active sites facing a central pore. Nature 392:306-311

145. Pestelli E, Caproni M, Giomi B, Volpi W, Spallanzani A, Cardinali C, Floriani I, Fabbri P (2001) Cetirizine reduces the number of tryptase-positive mast cells in psoriatic patients: a doubleblind controlled study. Int J Tissue React 23:97-103

146. Pestelli E, Floriani I, Fabbri P, Caproni M (2003) Cetirizine modulates adhesion molecule expression in a double-blind controlled study conducted in psoriatic patients. Int J Tissue React 25:1-8

147. Petersen LJ, Hansen U, Kristensen JK, Nielsen H, Skov PS, Nielsen HJ (1998) Studies on mast cells and histamine release in psoriasis: the effect of ranitidine. Acta Derm Venereol (Stockh) 78:190-193

148. Piliponsky AM, Levi-Schaffer F (2000) Regulation of apoptosis in mast cells. Apoptosis 5:435-441

149. Pincelli C, Fantini F, Romualdi P, Sevignani C, Lesa G, Benassi L, Giannetti A (1992) Substance P is diminished and vasoactive intestinal peptide is augmented in psoriatic lesions and these peptides exert disparate effects on the proliferation of cultured human keratinocytes. J Invest Dermatol 98:421-427

150. Pipkorn U, Andersson M (1987) Topical dermal anaesthesia inhibits the flare but not the weal response to allergen and histamine in the skin-prick test. Clin Allergy 17:307-311

151. Pipkorn U, Hammarlund A, Enerbäck L (1989) Prolonged treatment with topical glucocorticoids results in an inhibition of the allergen-induced weal-and-flare response and a reduction in skin mast cell numbers and histamine content. Clin Exp Allergy 19:19-25

152. Poncet P, Arock M, David B (1999) MHC class II-dependent activation of $\mathrm{CD} 4+\mathrm{T}$ cell hybridomas by human mast cells through superantigen presentation. J Leukoc Biol 66:105-112

153. Royer B, Varadaradjalou S, Saas P, Gabiot AC, Kantelip B, Féger F, Guillosson JJ, Kantelip JP, Arock M (2001) Autocrine regulation of cord blood-derived human mast cell activation by IL-10. J Allergy Clin Immunol 108:80-86

154. Saarinen J, Kalkkinen N, Welgus HG, Kovanen PT (1994) Activation of human interstitial procollagenases through direct cleavage of the Leu ${ }^{83}-\mathrm{Thr}^{84}$ bond by mast cell chymase. J Biol Chem 269:18134-18140

155. Saarinen JV, Harvima RJ, Naukkarinen A, Horsmanheimo M, Harvima IT (2001) The release of histamine is associated with the inactivation of mast cell chymase during immediate allergic wheal reaction in the skin. Clin Exp Allergy 31:593-601

156. Saarinen JV, Harvima RJ, Naukkarinen A, Horsmanheimo M, Harvima IT (2001) Interleukin-4-positive mast cells are highly associated with the extent of immediate allergic wheal reaction in the skin. Allergy 56:58-64 (Erratum: Allergy 2001;56:451)

157. Sabat R, Philipp S, Höflich C, Kreutzer S, Wallace E, Asadullah K, Volk H-D, Sterry W, Wolk K (2007) Immunopathogenesis of psoriasis. Exp Dermatol 16:779-798

158. Sawai N, Koike K, Mwamtemi HH, Kinoshita T, Kurokawa Y, Sakashita K, Higuchi T, Takeuchi K, Shiohara M, Kamijo T, Ito S, Kato T, Miyazaki H, Yamashita T, Komiyama A (1999) Thrombopoietin augments stem cell factor-dependent growth of human mast cells from bone-marrow multipotential hematopoietic progenitors. Blood 93:3703-3712

159. Sayama S, Iozzo RV, Lazarus GS, Schechter NM (1987) Human skin chymotrypsin-like proteinase chymase: subcellular localization to mast cell granules and interaction with heparin and other glycosaminoglycans. J Biol Chem 262:6808-6815

160. Sayed BA, Brown MA (2007) Mast cells as modulators of T-cell responses. Immunol Rev 217:53-64

161. Schechter NM, Sprows JL, Schoenberger OL, Lazarus GS, Cooperman BS, Rubin H (1989) Reaction of human skin chymotryp- sin-like proteinase chymase with plasma proteinase inhibitors. J Biol Chem 264:21308-21315

162. Schechter NM, Irani A-MA, Sprows JL, Abernethy J, Wintroub B, Schwartz LB (1990) Identification of a cathepsin G-like proteinase in the $\mathrm{MC}_{\mathrm{TC}}$ type of human mast cell. $\mathrm{J}$ Immunol 145:2652-2661

163. Schechter NM, Brass LF, Lavker RM, Jensen PJ (1998) Reaction of mast cell proteases tryptase and chymase with protease activated receptors (PARs) on keratinocytes and fibroblasts. J Cell Physiol 176:365-373

164. Schechter NM, Choi E-J, Selwood T, McCaslin DR (2007) Characterization of three distinct catalytic forms of human tryptase- $\beta$ : their interrelationships and relevance. Biochemistry 46:96159629

165. Schick C, Kamachi Y, Bartuski AJ, Çataltepe S, Schechter NM, Pemberton PA, Silverman GA (1997) Squamous cell carcinoma antigen 2 is a novel serpin that inhibits the chymotrypsin-like proteinases cathepsin $\mathrm{G}$ and mast cell chymase. J Biol Chem 272:1849-1855

166. Schmelz M, Luz O, Averbeck B, Bickel A (1997) Plasma extravasation and neuropeptide release in human skin as measured by intradermal microdialysis. Neurosci Lett 230:117-120

167. Scholzen TE, Steinhoff M, Bonaccorsi P, Klein R, Amadesi S, Geppetti P, Lu B, Gerard NP, Olerud JE, Luger TA, Bunnett NW, Grady EF, Armstrong CA, Ansel JC (2001) Neutral endopeptidase terminates substance P-induced inflammation in allergic contact dermatitis. J Immunol 166:1285-1291

168. Schubert C, Christophers E (1985) Mast cells and macrophages in early relapsing psoriasis. Arch Dermatol Res 277:352-358

169. Schwartz LB, Min HK, Ren S, Xia HZ, Hu J, Zhao W, Moxley G, Fukuoka Y (2003) Tryptase precursors are preferentially and spontaneously released, whereas mature tryptase is retained by HMC-1 cells, Mono-Mac- 6 cells, and human skin-derived mast cells. J Immunol 170:5667-5673

170. Sharlow ER, Paine CS, Babiarz L, Eisinger M, Shapiro S, Seiberg M (2000) The protease-activated receptor-2 upregulates keratinocyte phagocytosis. J Cell Sci 113:3093-3101

171. Siebenhaar F, Syska W, Weller K, Magerl M, Zuberbier T, Metz M, Maurer M (2007) Control of Pseudomonas aeruginosa skin infections in mice is mast cell-dependent. Am J Pathol 170:1910 1916

172. Skokos D, Goubran Botros H, Demeure C, Morin J, Peronet R, Birkenmeier G, Boudaly S, Mécheri S (2003) Mast cell-derived exosomes induce phenotypic and functional maturation of dendritic cells and elicit specific immune responses in vivo. J Immunol 170:3037-3045

173. Sperr WR, Agis H, Czerwenka K, Virgolini I, Bankl HC, Müller MR, Zsebo K, Lechner K, Valent P (1996) Effects of cyclosporin A and FK-506 on stem cell factor-induced histamine secretion and growth of human mast cells. J Allergy Clin Immunol 98:389_ 399

174. Stack MS, Johnson DA (1994) Human mast cell tryptase activates single-chain urinary-type plasminogen activator (pro-urokinase). J Biol Chem 269:9416-9419

175. Steinhoff M, Vergnolle N, Young SH, Tognetto M, Amadesi S, Ennes HS, Trevisani M, Hollenberg MD, Wallace JL, Caughey GH, Mitchell SE, Williams LM, Geppetti P, Mayer EA, Bunnett NW (2000) Agonists of proteinase-activated receptor 2 induce inflammation by a neurogenic mechanism. Nat Med 6:151-158

176. Steinhoff M, Neisius U, Ikoma A, Fartasch M, Heyer G, Skov PS, Luger TA, Schmelz M (2003) Proteinase-activated receptor-2 mediates itch: a novel pathway for pruritus in human skin. J Neurosci 23:6176-6180

177. Stellato C, de Paulis A, Ciccarelli A, Cirillo R, Patella V, Casolaro V, Marone G (1992) Anti-inflammatory effect of cyclosporin A on human skin mast cells. J Invest Dermatol 98:800-804 
178. Ständer S, Moormann C, Schumacher M, Buddenkotte J, Artuc M, Shpacovitch V, Brzoska T, Lippert U, Henz BM, Luger TA, Metze D, Steinhoff M (2004) Expression of vanilloid receptor subtype 1 in cutaneous sensory nerve fibers, mast cells, and epithelial cells of appendage structures. Exp Dermatol 13:129-139

179. Sugiyama H, Gyulai R, Toichi E, Garaczi E, Shimada S, Stevens SR, McCormick T, Cooper KD (2005) Dysfunctional blood and target tissue $\mathrm{CD} 4^{+} \mathrm{CD} 25^{\text {high }}$ regulatory T cells in psoriasis: mechanism underlying unrestrained pathogenic effector $\mathrm{T}$ cell proliferation. J Immunol 174:164-173

180. Suto H, Nakae S, Kakurai M, Sedgwick JD, Tsai M, Galli SJ (2006) Mast cell-associated TNF promotes dendritic cell migration. J Immunol 176:4102-4112

181. Taipale J, Lohi J, Saarinen J, Kovanen PT, Keski-Oja J (1995) Human mast cell chymase and leukocyte elastase release latent transforming growth factor- $\beta 1$ from the extracellular matrix of cultured human epithelial and endothelial cells. J Biol Chem 270:4689-4696

182. Tam EK, Caughey GH (1990) Degradation of airway neuropeptides by human lung tryptase. Am J Respir Cell Mol Biol 3:27-32

183. Tani K, Ogushi F, Kido H, Kawano T, Kunori Y, Kamimura T, Cui P, Sone S (2000) Chymase is a potent chemoattractant for human monocytes and neutrophils. J Leukoc Biol 67:585-589

184. Tausk F, Undem B (1995) Exogenous but not endogenous substance $\mathrm{P}$ releases histamine from isolated human skin fragments. Neuropeptides 29:351-355

185. Teahan J, Harrison R, Izquierdo M, Stein RL (1989) Substrate specificity of human fibroblast stromelysin. Hydrolysis of substance $\mathrm{P}$ and its analogues. Biochemistry 28:8497-8501

186. Terakawa M, Tomimori Y, Goto M, Fukuda Y (2006) Mast cell chymase induces expression of chemokines for neutrophils in eosinophilic EoL-1 cells and mouse peritonitis eosinophils. Eur J Pharmacol 538:175-181

187. Tkaczyk C, Okayama Y, Woolhiser MR, Hagaman DD, Gilfillan AM, Metcalfe DD (2001) Activation of human mast cells through the high affinity IgG receptor. Mol Immunol 38:12891293

188. Toruniowa B, Jablonska S (1988) Mast cells in the initial stages of psoriasis. Arch Dermatol Res 280:189-193

189. Töyry S, Fräki JE, Tammi R (1988) Mast cell density in psoriatic skin. The effect of PUVA and corticosteroid therapy. Arch Dermatol Res 280:282-285

190. Uyemura K, Yamamura M, Fivenson DF, Modlin RL, Nickoloff BJ (1993) The cytokine network in lesional and lesion-free psoriatic skin is characterized by a T-helper type 1 cell-mediated response. J Invest Dermatol 101:701-705

191. van de Kerkhof PC, Goos M, Christophers E, Baudin M, Dupuy $P$ (1995) Inhibitor of the release of mast cell mediators does not improve the psoriatic plaque. Skin Pharmacol 8:25-29

192. van Overveld FJ, Jorens PG, Rampart M, de Backer W, Vermeire PA (1991) Tumour necrosis factor stimulates human skin mast cells to release of histamine and tryptase. Clin Exp Allergy 21:711-714

193. Walls AF, Brain SD, Desai A, Jose PJ, Hawkings E, Church MK, Williams TJ (1992) Human mast cell tryptase attenuates the vasodilator activity of calcitonin gene-related peptide. Biochem Pharmacol 43:1243-1248

194. Walsh LJ, Trinchieri G, Waldorf HA, Whitaker D, Murphy GF (1991) Human dermal mast cells contain and release tumor necrosis factor $\alpha$, which induces endothelial leukocyte adhesion molecule 1. Proc Natl Acad Sci (USA) 88:4220-4224

195. Walter M, Plotnick M, Schechter NM (1996) Inhibition of human mast cell chymase by secretory leukocyte proteinase inhibitor: enhancement of the interaction by heparin. Arch Biochem Biophys 327:81-88
196. Walter M, Sutton RM, Schechter NM (1999) Highly efficient inhibition of human chymase by $\alpha(2)$-macroglobulin. Arch Biochem Biophys 368:276-284

197. Wang H, He S (2006) Induction of lactoferrin and IL-8 release from human neutrophils by tryptic enzymes via proteinase activated receptor-2. Cell Biol Int 30:688-697

198. Wang HW, Tedla N, Lloyd AR, Wakefield D, McNeil HP (1998) Mast cell activation and migration to lymph nodes during induction of an immune response in mice. J Clin Invest 102:1617-1626

199. Wang HW, McNeil HP, Husain A, Liu K, Tedla N, Thomas PS, Raftery M, King GC, Cai ZY, Hunt JE (2002) $\delta$ Tryptase is expressed in multiple human tissues, and a recombinant form has proteolytic activity. J Immunol 169:5145-5152

200. Wang LH, Ahmad S, Benter IF, Chow A, Mizutani S, Ward PE (1991) Differential processing of substance P and neurokinin A by plasma dipeptidyl(amino)peptidase IV, aminopeptidase M and angiotensin converting enzyme. Peptides 12:1357-1364

201. Waskow C, Bartels S, Schlenner SM, Costa C, Rodewald H-R (2007) Kit is essential for PMA-inflammation-induced mast-cell accumulation in the skin. Blood 109:5363-5370

202. Weidner N, Austen KF (1993) Heterogeneity of mast cells at multiple body sites: fluorescent determination of avidin binding and immunofluorescent determination of chymase, tryptase, and carboxypeptidase content. Path Res Pract 189:156-162

203. Welker P, Grabbe J, Gibbs B, Zuberbier T, Henz BM (1999) Human mast cells produce and differentially express both soluble and membrane-bound stem cell factor. Scand J Immunol 49:495500

204. Westin U, Polling Å, Ljungkrantz I, Ohlsson K (1999) Identification of SLPI (secretory leukocyte protease inhibitor) in human mast cells using immunohistochemistry and in situ hybridisation. Biol Chem 380:489-493

205. Whitaker-Menezes D, Schechter NM, Murphy GF (1995) Serine proteinases are regionally segregated within mast cell granules. Lab Invest 72:34-41

206. Willis EF, Clough GF, Church MK (2004) Investigation into the mechanisms by which nedocromil sodium, frusemide and bumetanide inhibit the histamine-induced itch and flare response in human skin in vivo. Clin Exp Allergy 34:450-455

207. Wong GW, Yasuda S, Madhusudhan MS, Li L, Yang Y, Krilis SA, Sali A, Stevens RL (2001) Human tryptase $\varepsilon$ (PRSS22), a new member of the chromosome 16p13.3 family of human serine proteases expressed in airway epithelial cells. J Biol Chem 276:49169-49182

208. Wong GW, Foster PS, Yasuda S, Qi JC, Mahalingam S, Mellor EA, Katsoulotos G, Li L, Bouce JA, Krilis SA, Stevens RL (2002) Biochemical and functional characterization of human transmembrane tryptase (TMT)/tryptase $\gamma$. J Biol Chem 277:41906-41915

209. Xiang Z, Nilsson G (2000) IgE receptor-mediated release of nerve growth factor by mast cells. Clin Exp Allergy 30:1379_ 1386

210. Xiang Z, Ahmed AA, Möller C, Nakayama K, Hatakeyama S, Nilsson $G$ (2001) Essential role of the prosurvival bcl-2 homologue A1 in mast cell survival after allergic activation. J Exp Med 194:1561-1569

211. Yamamoto T, Katayama I, Nishioka K (1997) Expression of stem cell factor in basal cell carcinoma. Br J Dermatol 137:709-713

212. Yamamoto T, Katayama I, Nishioka K (2000) Possible contribution of stem cell factor in psoriasis vulgaris. J Dermatol Sci 24:171-176

213. Yanagida M, Fukamachi H, Ohgami K, Kuwaki T, Ishii H, Uzumaki H, Amano K, Tokiwa T, Mitsui H, Saito H, Iikura Y, Ishizaka T, Nakahata T (1995) Effects of T-helper 2-type cytokines, interleukins-3 (IL-3), IL-4, IL-5, and IL-6 on the survival of cultured human mast cells. Blood 86:3705-3714 
214. Yuan J, Beltman J, Gjerstad E, Nguyen MT, Sampang J, Chan H, Janc JW, Clark JM (2006) Expression and characterization of recombinant $\gamma$-tryptase. Protein Expr Purif 49:47-54

215. Zhang S, Anderson DF, Bradding P, Coward WR, Baddeley SM, MacLeod JD, McGill JI, Church MK, Holgate ST, Roche WR (1998) Human mast cells express stem cell factor. J Pathol 186:59-66

216. Zhao W, Oskeritzian CA, Pozez AL, Schwartz LB (2005) Cytokine production by skin-derived mast cells: endogenous proteases are responsible for degradation of cytokines. J Immunol 175:2635-2642

217. Zhao W, Kepley CL, Morel PA, Okumoto LM, Fukuoka Y, Schwartz LB (2006) Fc $\gamma$ RIIa, not Fc $\gamma$ RIIb, is constitutively and functionally expressed on skin-derived human mast cells. J Immunol 177:694-701

218. Zheng Y, Danilenko DM, Valdez P, Kasman I, Eastham-Anderson J, Wu J, Ouyang W (2007) Interleukin-22, a $\mathrm{T}_{\mathrm{H}} 17$ cytokine, mediates IL-23-induced dermal inflammation and acanthosis. Nature 445:648-651

219. Zonneveld IM, Meinardi MM, Karlsmark T, Johansen UB, Kuiters GR, Hamminga L, Staberg B, Veen van't AJ, Bossuyt PM,
Niel VanJC, Bos JD (1997) Ranitidine does not affect psoriasis: a multicenter, double-blind, placebo-controlled study. J Am Acad Dermatol 36:932-934

\section{Related articles recently published in Archives of Dermatological Research:}

220. Ashenagar MS, Sugihara K, Maeda A, Isogai R, Takahashi M, Aisu K, Horiuchi A, Aragane Y, Kawada A, Tezuka T (2007) The presence of tryptase-positive and bikunin-negative mast cells in psoriatic skin lesions. Arch Dermatol Res 298:421-426

221. Mrowietz U, Elder JT, Barker J (2006) The importance of disease associations and concomitant therapy for the long-term management of psoriasis patients. Arch Dermatol Res 298:309-319

222. Remrod C, Lonne-Rahm S, Nordlind K (2007) Study of substance $\mathrm{P}$ and its receptor neurokinin-1 in psoriasis and their relation to chronic stress and pruritus. Arch Dermatol Res 299:85-91 